\title{
Changes in the Distribution of Extracellular Matrix Components Accompany Early Morphogenetic Events of Mammalian Cortical Development
}

\author{
Allan M. Sheppard, Sarah K. Hamilton, and Alan L. Pearlman \\ Departments of Cell Biology and Neurology, Washington University School of Medicine, St. Louis, Missouri 63110
}

As a step in defining the molecular environment for development of the mammalian cerebral cortex, we have used immunohistochemistry to analyze the distribution and remodeling of three major extracellular matrix (ECM) components, fibronectin, chondroitin sulfate proteoglycan (CSPG), and tenascin, during embryonic and early postnatal stages in the mouse. Fibronectin and CSPG are distributed throughout the proliferative zone that initially comprises the thin wall of the telencephalic vesicle, but their distribution changes as newly generated cells form the preplate just beneath the pia. Immunolabeling for CSPG becomes most prominent in the preplate, and fibronectin becomes restricted to that layer. Just after this change occurs, processes of preplate neurons, visualized with antibodies to neurofilaments, become evident within the matrix-rich preplate zone. The association of fibronectin and CSPG with preplate cells persists as cortical plate neurons divide the preplate; both ECM components are now most prominent in the marginal zone and subplate, the layers above and below the cortical plate that are preplate derived. Within the preplate and its derivatives, immunolabeling of fibronectin is punctate and closely associated with radial glial processes, while labeling of CSPG is more intense and diffuse. Labeling of fibronectin and CSPG declines rapidly as the cortical plate begins to differentiate into cortex; labeling for tenascin first appears at this stage in the most mature layers, the marginal zone and subplate, then gradually becomes widespread throughout all of cortex and subcortical white matter. In early postnatal life, tenascin is eliminated from the hollows of the vibrissal barrels in the somatosensory region; it then declines rapidly throughout cortex.

The association of both fibronectin and CSPG with preplate cells and the distribution of fibronectin along radial glia during early cortical development suggest that one or both

\footnotetext{
Received May 8, 1991; revised July 12, 1991; accepted July 30, 1991.

We thank Carol Boyd, Jeanette Cohen, William Puckett, and Judy Speck for technical assistance, and Drs. Tom Broekelman, John McDonald, Mario Burdon, John Wood, and Miyuki Yamamoto for generously providing antibodies. We are very grateful to Drs. Marla Luskin, John McDonald, Dennis O'Leary, and Joshua Sanes for many informative discussions during the course of this work. This study was supported by Research Grant RO1 EY00621 from the National Eye Institute, NIH; a fellowship to A.M.S. from the McDonnell Centers for Higher Brain Function and Cellular and Molecular Neurobiology, Washington University; and an undergraduate research fellowship to S.K.H. from the National Science Foundation.

Correspondence should be addressed to Alan L. Pearlman, M.D., Department of Cell Biology-Box 8228, Washington University School of Medicine, 660 South
} Euclid Avenue, St. Louis, MO 63110.

Copyright (C) 1991 Society for Neuroscience $0270-6474 / 91 / 113928-15 \$ 05.00 / 0$ of these transient cell types might produce specific ECM components or induce their local deposition. The spatial and temporal distribution of fibronectin and CSPG suggests a role in defining a destination for migrating neurons that form the cortical plate and in delineating the pathway for early axonal extension. In contrast, the relatively late appearance of tenascin correlates best with the formation of astrocytes and their processes rather than with the establishment of cortical layers or major axonal pathways. These events are well underway before labeling of tenascin is evident.

During early development of mammalian cerebral cortex, newly generated neurons migrate, accumulate in layers, and extend growth cone-guided processes to establish local and distant interconnections. The molecular interactions responsible for these events in cortex are at present largely undefined, but in other parts of the embryo extracellular matrix (ECM) components play an important role in many major developmental rearrangements including gastrulation (Boucaut et al., 1984), the migration of primordial germ cells (Donovan et al., 1987), and the migration and accumulation of neural crest cells (Bronner-Fraser, 1986; Duband et al., 1986; Rogers et al., 1986; Sternberg and Kimber, 1986).

Although a matter of controversy for many years, it now seems clear that ECM components are involved in development of the CNS as well (Sanes, 1989; Reichardt and Tomaselli, 1991). Glycosaminoglycans, defined by labeling with cationic dyes, are present in the cerebral cortex of the mouse (Derer and Nakanishi, 1983; Nakanishi, 1983; Bruckner et al., 1985) and in the chick's optic tectum just ahead of arriving optic nerve axons (Krayanek, 1980). Immunolabeling with antibodies against fibronectin (FN; Hatten et al., 1982; Stewart and Pearlman, 1987; Chun and Shatz, 1988; Stallcup et al., 1989), proteoglycans (Aquino et al., 1984; Margolis and Margolis, 1989; Snow et al., 1990b), hyaluronectin (Delpech and Delpech, 1984; Bignami and Delpech, 1985), laminin (Liesi, 1985; Letourneau et al., 1988; Liesi and Silver, 1988; McLoon et al., 1988; Hagg et al., 1989), tenascin (Crossin et al., 1989; Steindler et al., 1989), and thrombospondin (O'Shea et al., 1990) has been demonstrated in the developing CNS of the rodent, and extracellular material that has not been characterized with antibody markers is evident with electron microscopy in the cortical subplate and marginal zones (Derer and Nakanishi, 1983; Nakanishi, 1983; Hankin and Silver, 1988).

An understanding of the role of individual ECM components in cortical devclopment will require a precise definition of the timing and location of their expression. To this end, we have 
used immunolabeling to determine the spatial and temporal distribution of three major classes of ECM components, FN, chondroitin sulfate proteoglycan (CSPG), and tenascin, in the developing cerebral cortex of the mouse from embryonic day 11 (E11) through postnatal day 14 (P14). The FNs are a set of large, dimeric glycoproteins, produced from a single gene by alternative splicing, that are involved in cell adhesion, migration, and differentiation (Hynes, 1990). Chondroitin sulfate is one of several types of glycosaminoglycan that are covalently linked to various protein cores to form the large family of proteoglycans present in ECM and on cell surface membranes (Gallagher, 1989). There is evidence that CSPGs may restrict migration of neural crest cells (Tucker and Erickson, 1984, Perris and Johansson, 1990) and may also inhibit neurite outgrowth in culture (Snow et al., 1990a). Tenascin, which is similar or identical to GMEM (Bourdon et al., 1983), myotendinous antigen (Chiquet and Fambrough, 1984), hexabrachion protein (Erickson and Iglesias, 1984), cytotactin (Grumet et al., 1985), and $\mathrm{J} 1_{200 / 220}$ (Kruse et al., 1985), is a modular glycoprotein that is prominently expressed during development and tumor formation (Chiquet, 1989; Erickson and Bourdon, 1989). Conflicting roles have been ascribed to tenascin; it has been suggested that it provides a barrier to neural crest cell migration (Tan et al., 1987; Bronner-Fraser, 1988) and neurite outgrowth (Steindler et al., 1989; Faissner and Kruse, 1990), but may support migration of cerebellar granule cells (Chuong et al., 1987).

In the present study we demonstrate a rapidly changing distribution pattern for ECM components in developing cerebral cortex. FN is initially distributed along the radial glia that are thought to guide migrating neurons (Ramon y Cajal, 1891; Rakic, 1972). FN and CSPG are both closely associated with preplate cells, a transient, early population of neurons that are important to subsequent cortical plate formation (Marin-Padilla, 1971; Raedler and Raedler, 1978; Luskin and Shatz, 1985), and both are expressed over a similar time course early in cortical development. In contrast, tenascin is not evident until late in embryonic development, at a time when the cortical plate has begun to differentiate into cortex, radial glia are transforming into astrocytes, and immunoreactivity to FN and CSPG has declined or disappeared.

A preliminary report of this work has appeared in abstract form (Sheppard and Pearlman, 1990).

\section{Materials and Methods}

Antibodies. The following primary antibodies were used to label sections: an affinity-purified polyclonal antiserum (rabbit) to human fibronectin (abFN; 1:200; provided by J. McDonald and T. Broekelman; Villiger et al., 1981); an antiserum (rabbit) to human tenascin (abTEN; IgG fraction, $1: 25$; provided by $M$. Bourdon); a monoclonal antibody to chondroitin sulfate proteoglycan (abCSPG; Sigma; 1:600; Avnur and Geiger, 1984); monoclonal antibodies RC1 and RC2 (undiluted hybridoma supernatants derived from cells provided by M. Yamamoto), which label cytoskeletal proteins of radial glia (Misson et al., 1988; Culican et al., 1990; Edwards et al., 1990); and monoclonal antibodies to neurofilaments [abNF: SMI-31 (1:400; Sternberger-Meyer Immunochemicals, Jarrettsville, MD) and RT97 (1:1000; provided by J. Wood; Wood et al., 1985)]. Secondary antibodies $(1: 100$ or $1: 200)$ included tetramethylrhodamine isothiocyanate (TRITC)-conjugated donkey antirabbit IgG, TRITC-conjugated rabbit anti-mouse IgM, and fluorescein isothiocyanate (FITC)-conjugated goat anti-mouse IgG and IgM (Jackson Labs, West Grove, PA).

Immunolabeling of tissue sections. The methods for immunolabeling sections of the embryonic brain have been described previously (Stewart and Pearlman, 1987). Briefly, timed pregnancies were produced by matings of $\mathrm{C} 57 \mathrm{Bl} / 6 \mathrm{~J}$ mice (Jackson Labs, Bar Harbor, ME). Females were checked for vaginal plugs each morning; the day of conception was designated embryonic day $0(\mathrm{E} 0)$. Embryos obtained by cesarian section were fixed by immersion in 4\% paraformaldehyde in PBS ( $\mathrm{pH} 7.4$ ) for $1-2 \mathrm{hr}$ at $4^{\circ} \mathrm{C}$. During fixation the scalp and skull were opened (E11$12)$ or the brain was removed from the skull (E13 and older). After rinses with PBS, brains were immersed in $30 \%$ sucrose overnight at $4^{\circ} \mathrm{C}$ frozen in liquid nitrogen, and sectioned $(16-20 \mu \mathrm{m})$ with a cryostat. Sections were dried on gelatin-coated slides at room temperature and stored at $-20^{\circ} \mathrm{C}$ until use. For immunolabeling with $\mathrm{RCl}$, unfixed embryos were frozen in liquid nitrogen; cryostat sections were fixed bricfly on the slide with paraformaldehyde $(1 \%, 2 \mathrm{~min})$, rinsed in PBS, permeabilized with methyl alcohol $\left(-70^{\circ} \mathrm{C}, 5 \mathrm{~min}\right)$, then rinsed with PBS.

Immunolabeling was carried out in a dark, humidified chamber. All rinses were with PBS (pH 7.4), and antibody dilutions were in $1 \%$ fish gelatin (Sigma Chemical) in PBS. Tris-buffered saline was substituted for PBS for immunolabeling with the anti-neurofilament antibodies. Sections were rehydrated with buffer $(5 \mathrm{~min})$, blocked with $1 \%$ fish gelatin in buffer, and incubated with primary antibodies for $1 \mathrm{hr}(\mathrm{RCl}$ $\mathrm{RC} 2$, and abNF) at room temperature, or overnight at $4^{\circ} \mathrm{C}$ (abFN, abCSPG, abTEN). For double labeling with $\mathrm{RC1}$ or $\mathrm{RC} 2$ and $\mathrm{abFN}$, primary antibodies were applied sequentially (abFN first) to avoid the prospect of labeling the small amount of fibronectin in the serum-containing hybridoma supernatant. After three rinses, sections were incubated with fluorescently tagged secondary antibodies for $1 \mathrm{hr}$, rinsed, coverslipped after application of $0.01 \%$ p-phenylenediamine (Sigma) in glycerin (Johnson and Nogueira-Araujo, 1981), and examined with epifluorescence microscopy (Nikon Labophot).

Controls. In each experiment, control sections were incubated with nonimmune IgG or diluent instead of the primary antibody. As an additional control, sections from each age were incubated with abFN that had been preincubated with fibronectin (Stewart and Pearlman, 1987). No labeling of the neuropil, blood vessels, or pia-arachnoid was apparent in these controls.

Antibody specificity. The following evidence indicates that the antiserum to fibronectin used in this study is likely to be labeling a molecule that is closely related to fibronectin: (1) abFN labeling is demonstrable with two different affinity-purified antisera (Stewart and Pearlman, 1987), onc against human plasma fibroncetin (Villiger ct al., 1981) and the other against cellular fibronectin from the hamster (Schwarzbauer et al., 1983); (2) immunolabeling is abolished by preincubating the antiserum with fibronectin (Stewart and Pearlman, 1987); and (3) immunolabeling with a similar distribution is demonstrable with a different set of antibodies in both rat (Stallcup et al., 1989) and cat (Chun and Shatz, 1988). The monoclonal antibody to CSPG has been shown to recognize chondroitin sulfate by solid-phase radioimmunoassay with purified glycosaminoglycans, sensitivity of the antigen to purified chondroitinases, and immunoprecipitation of sulfate-containing materials from cells and culture media (Avnur and Geiger, 1984). The antibody may cross-react with heparan sulfate, but not with heparin or dermatin sulfate (Avnur and Geiger, 1984). The antiserum to tenascin does not cross-react with laminin, fibronectin, or collagens I, III, and VI (M. Bourdon, personal communication). The distribution of immunolabeling we demonstrate in cortex is similar to that found by other laboratories with two different antibodies (Godfraind et al., 1988; Crossin et al., 1989; Steindler et al., 1989)

Semithin plastic sections. After immersion fixation for $2 \mathrm{hr}(4 \%$ paraformaldehyde, $0.5 \%$ glutaraldehyde in phosphate buffer, $\mathrm{pH} 7.2$ ), brains were rinsed in PBS; fixed for $30 \mathrm{~min}$ in $1 \% \mathrm{OsO}_{4}$; rinsed; dehydrated through a graded series of ethanol/ $\mathrm{H}_{2} \mathrm{O}$ solutions; immersed in propylene oxide (Polysciences) for $45 \mathrm{~min}$, in 1:1 propylene oxide/Araldite 502 (Polysciences) overnight, and then in undiluted Araldite for $7 \mathrm{hr}$; and cured at $60^{\circ} \mathrm{C}$ overnight. Sections $1-4 \mu \mathrm{m}$ were cut on an ultramicrotome and stained with $1 \%$ toluidine blue (Fisher).

\section{Results}

\section{Stages of early cortical development}

To facilitate description of the experimental results, we have divided the events of early cortical development into three stages. In the ventricular zone (VZ) stage (Fig. 1; E11), the dorsolateral wall of the telencephalic vesicle consists of a pseudostratified columnar epithelium made up of cells undergoing rapid division (Sauer, 1935; Angevine and Sidman, 1961). No postmitotic neurons are evident outside the ventricular zone. The preplate 

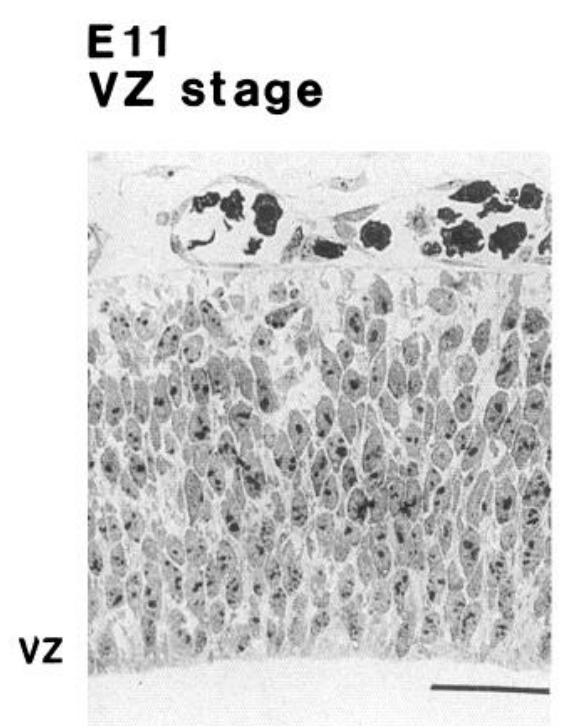

E12 PPZ stage

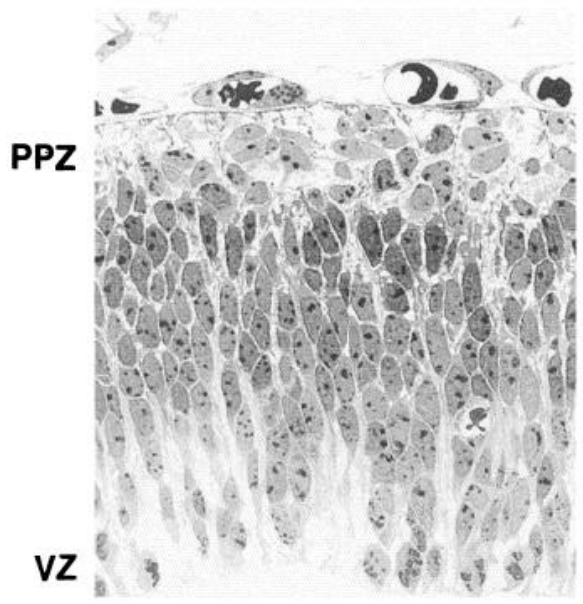

E13 CP stage

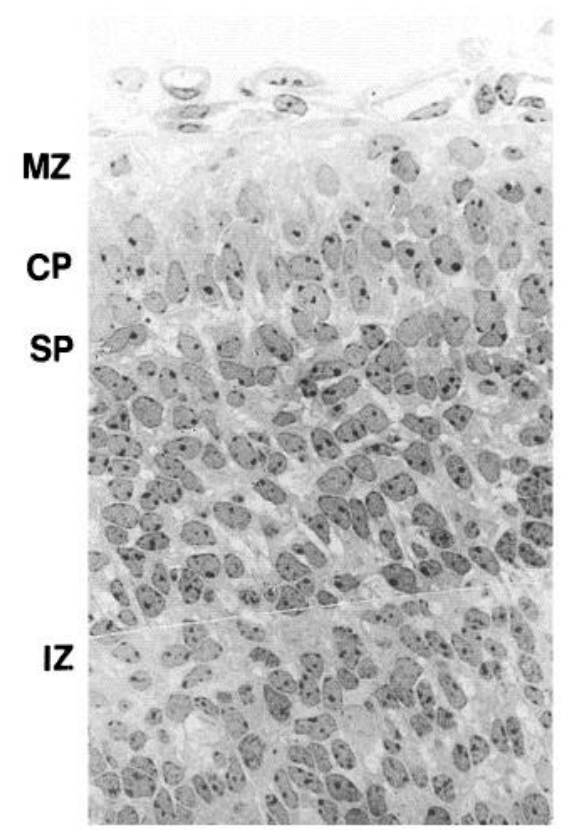

Figure 1. Stages of early cortical development: photomicrographs of toluidine blue-stained, plastic-embedded coronal sections from the dorsolateral wall of the telencephalic vesicle at the embryonic ages indicated (E11-13). The pial surface is at the top of the figure, and the ventricle is at the bottom. E11, Ventricular zone $(V Z)$ stage. The wall of the telencephalic vesicle consists of radially aligned cell bodies forming a pseudostratified columnar epithelium with no apparent lamination. E12, Preplate zone $(P P Z)$ stage. Pale, horizontally aligned nuclei of the first postmitotic neurons form a two to three cell thick preplate just beneath the pia. E13, Cortical plate $(C P)$ stage. A compact layer of cortical plate cells has formed, displacing a few preplate cells into the cell-sparse marginal zone $(M Z)$ above the cortical plate and the remainder into the subplate $(S P)$ below the cortical plate. Cells in the intermediate zone (IZ) are migrating toward the cortical plate. Scale bar, $20 \mu \mathrm{m}$.

zone (PPZ) stage (Fig. 1; E12) is characterized by the appearance of the first postmitotic neurons (Raedler and Raedler, 1978; Luskin and Shatz, 1985), which form the two to three cell thick preplate zone (also called the primordial plexiform zone; MarinPadilla, 1978) just beneath the pia. In the cortical plate (CP) stage (Fig. 1; E13), cells that will eventually form the definitive layers of the cortex accumulate in a dense layer within the preplate. Formation of the cortical plate within the preplate (MarinPadilla, 1978) divides the latter into the marginal zone above and the subplate below; both the marginal zone and the subplate contain the former preplate cells (Retzius, 1893; Marin-Padilla, 1971, 1972; Raedler and Raedler, 1978; Luskin and Shatz, 1985).

Each of these three stages of early cortical development has been arbitrarily assigned to an embryonic day based on its prominence on that day in the dorsolateral wall of the cerebral vesicle, approximately halfway between the anterior and posterior pole. Since there is a prominent ventrolateral to dorsomedial gradient in telencephalic development (Smart and Smart, 1982), the PPZ stage actually appears gradually in the ventrolateral wall late on E11 or early on E12 and continues to be present in the dorsomedial wall late on E12. The appearance of the cortical plate follows a similar progression, beginning late on E12 and extending through most of E13.

\section{Changing distribution of FN and CSPG}

In the $\mathrm{VZ}$ stage, immunoreactivity to abFN is evident as small punctate collections that are prominent around cells near the ventricular surface but extend throughout the cerebral wall (Fig.
2, VZ stage). Immunolabeling with the abCSPG is similarly distributed. However, it is more prominent than abFN immunolabeling, and also more widespread rather than punctate (Fig. 2, VZ stage). Intense immunoreactivity to both antibodies is present in the pia-arachnoid covering the brain; abFN labeling is also present in association with blood vessels (Fig. 2).

As postmitotic neurons leave the ventricular zone to form the preplate, there is a striking shift in the distribution of immunoreactivity to abFN and abCSPG. Instead of the distribution throughout the cerebral wall evident in the VZ stage, the puncta of abFN labeling are primarily in the preplate zone, and abCSPG labeling becomes much more prominent in the same layer (Fig. 2, PPZ stage). At this stage, immunolabeling with abNF first demonstrates neuronal processes in the lateral wall of the cerebral vesicle. The temporal relationship between the appearance of these processes and the change in distribution of abFN labeling is evident in a photographic montage of the dorsolateral wall of the telencephalic vesicle at E12 (Fig. 3). As a consequence of the ventrolateral to dorsomedial developmental gradient (Smart and Smart, 1982), both the VZ stage and the PPZ stage are evident in a single coronal section. The initial shift in FN and CSPG distribution takes place just as the first processes become evident with abNF. These processes are confined to the FN-CSPG-rich preplate zone as they advance; most appear to arise directly from preplate cells and traverse the preplate tangentially for short distances.

The distribution of abFN and abCSPG labeling changes again as the cortical plate forms within the preplate. The cortical plate 

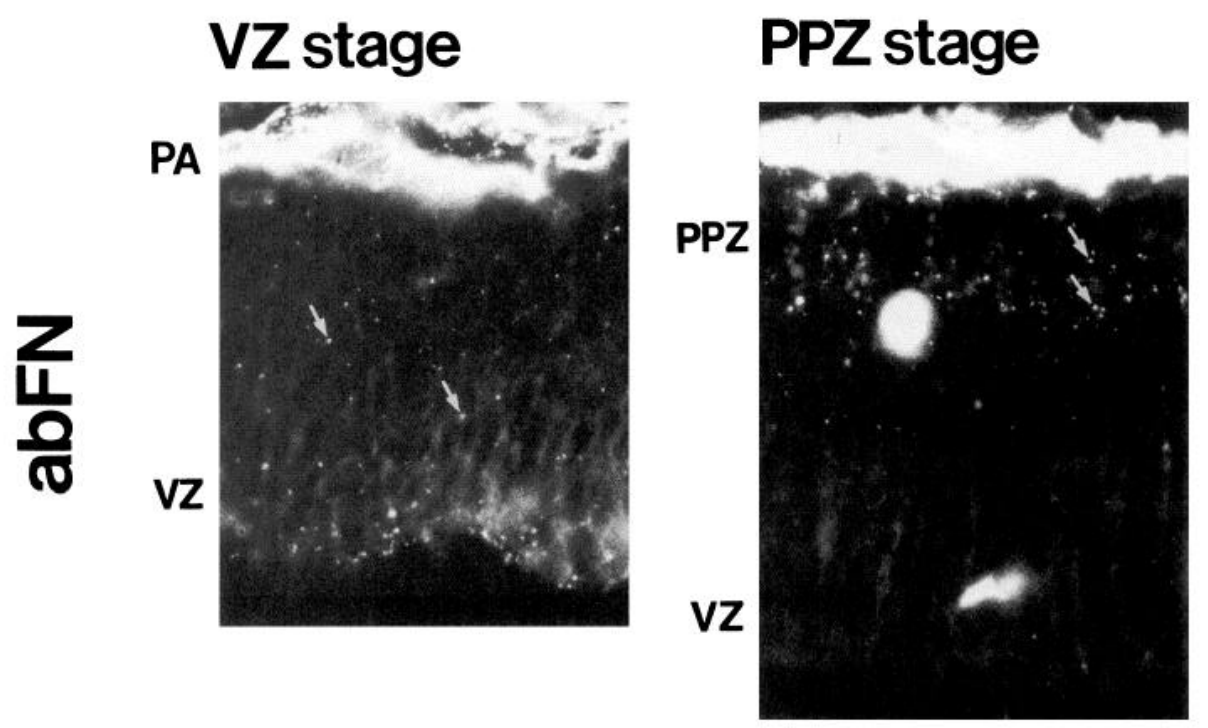

\section{CPstage}

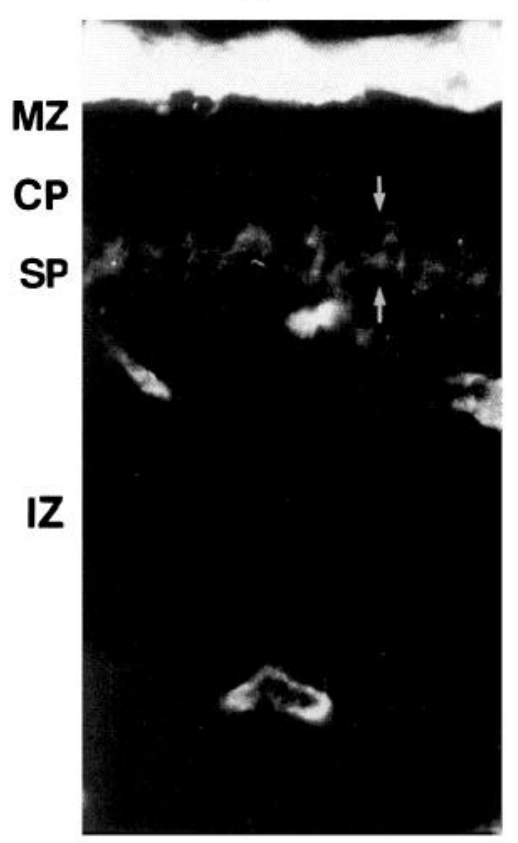

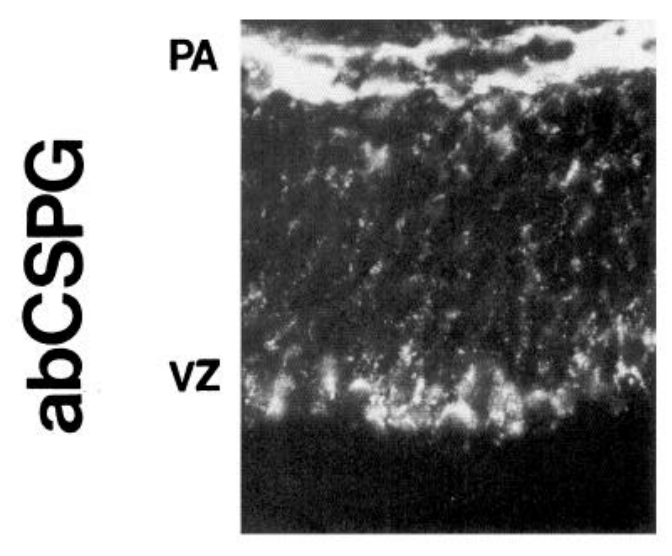
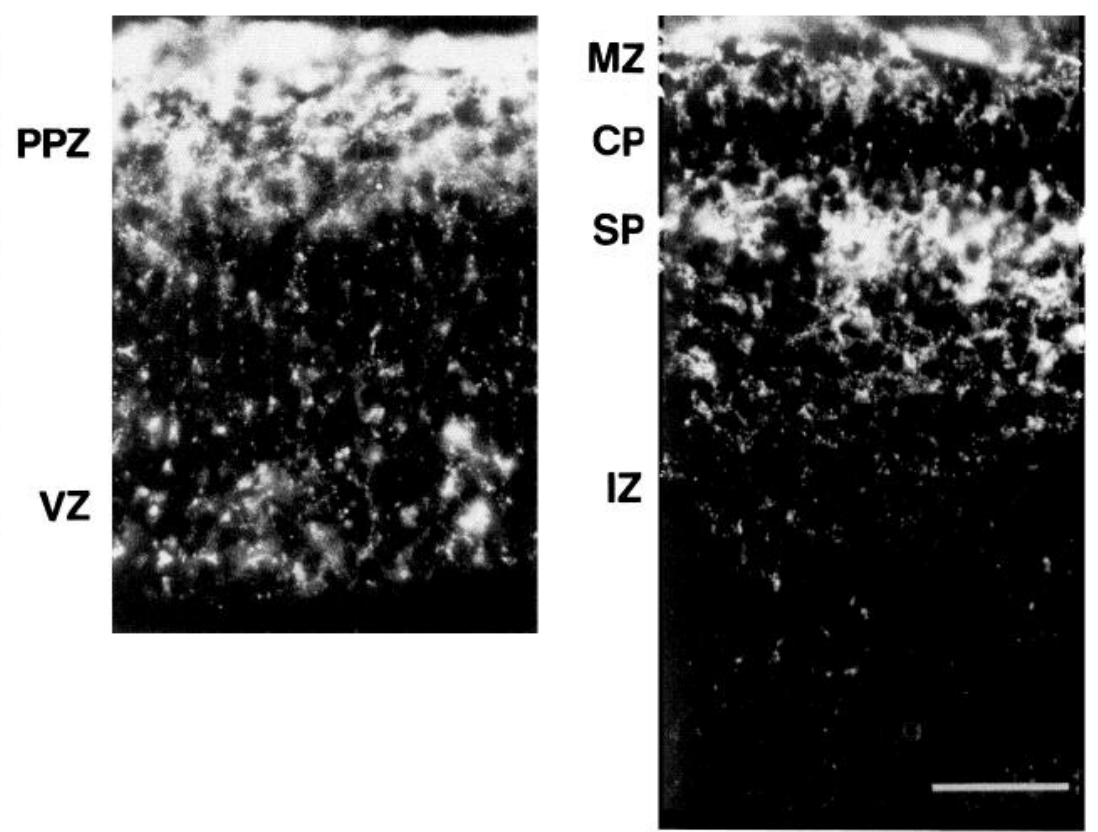

Figure 2. Changes in the distribution of FN and CSPG correspond to changes in position of the preplate neurons: immunofluorescent double labeling of coronal sections of the cerebral hemisphere with abFN (TRITC-tagged second antibody) and abCSPG (FITC-tagged second antibody). $V Z$ stage, Punctate labeling (arrows) with abFN is present throughout the ventricular zone $(V Z)$, which extends from the ventricle to the brightly labeled pia-arachnoid $(P A)$, with somewhat more prominence near the ventricle. Labeling with abCSPG is similarly distributed, but less punctate. $P P Z$ stage, Punctate labeling (arrows) with abFN is now primarily in the preplate zone ( $P P Z)$, and preplate labeling with abCSPG is very prominent. $C P$ stage, Diffuse labeling (between arrows) with abFN is present in the subplate (SP), and prominent labeling with abCSPG is evident in the subplate, marginal zone $(M Z)$, and upper intermediate zone $(I Z)$. Both FN and CSPG are almost completely absent from the cortical plate (CP). Scale bar, $20 \mu \mathrm{m}$.

is almost completely free of immunoreactivity; diffuse abFN and abCSPG labeling is prominent in the subplate beneath the cortical plate (Fig. 2, CP stage). Labeling with abCSPG is also prominent in the marginal zone above the cortical plate; abFN labeling is present in this layer but is more difficult to demonstrate there because of the very strong labeling of the immediately adjacent pia-arachnoid. Immunolabeling with abFN declines during the early CP stage and is no longer detectable by 


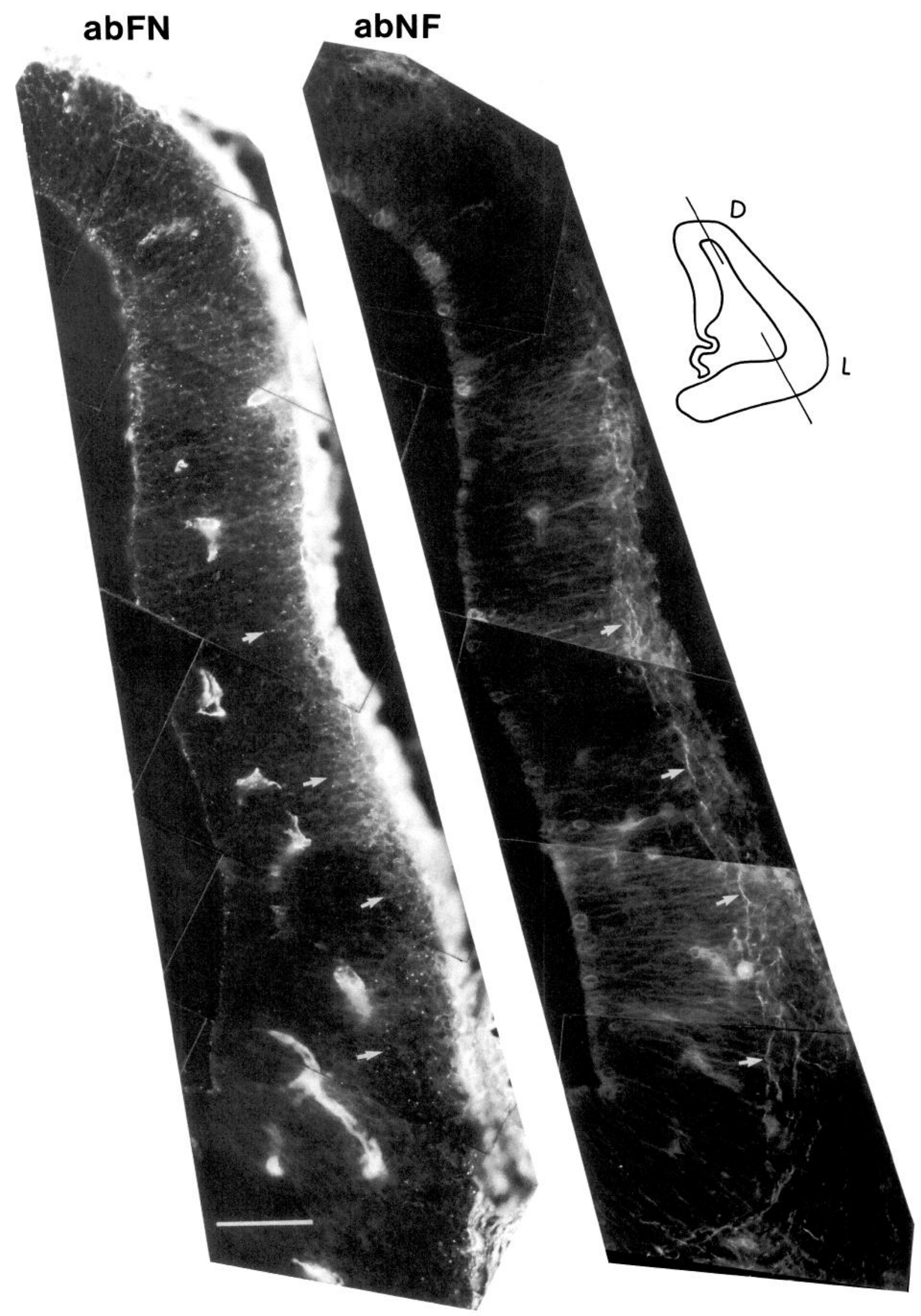




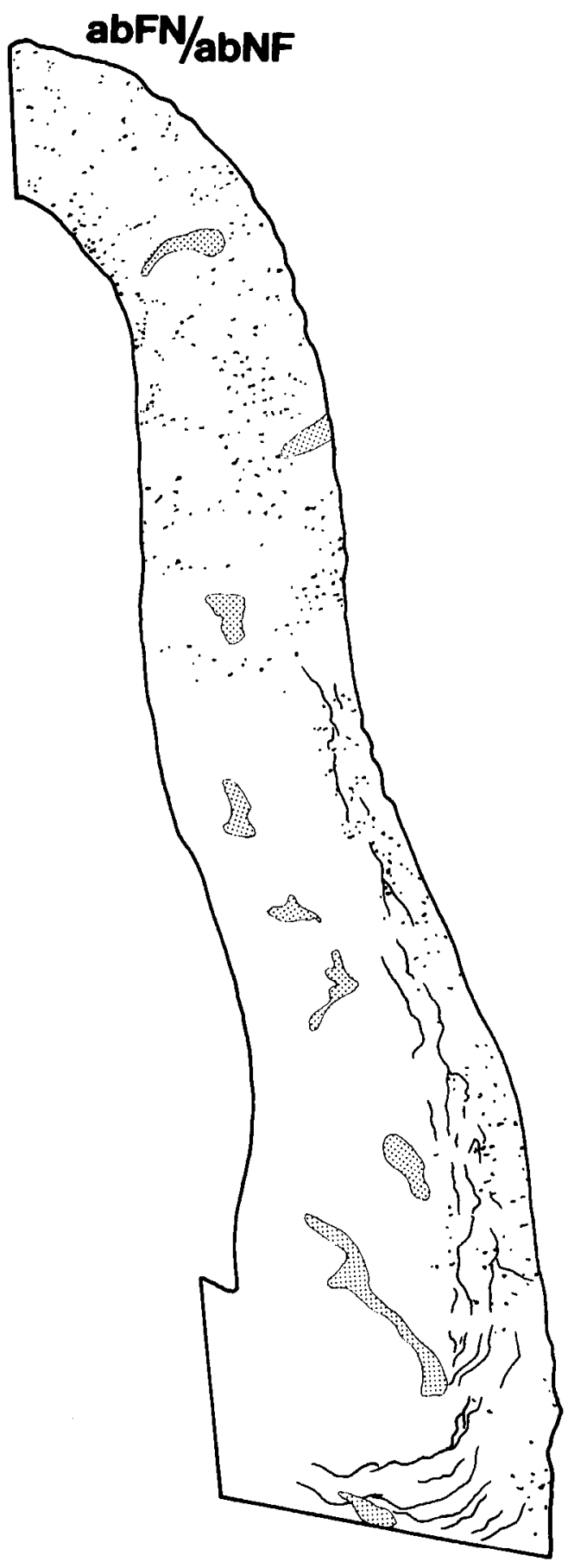

the late CP stage (data not shown; see Stewart and Pearlman, 1987). Labeling with abCSPG remains strong in both the marginal zone and subplate layers during the late $\mathrm{CP}$ stage (see Fig. 6, CP stage-late), but declines soon thereafter as cortical differentiation begins (see Fig. 6, CTX stage-early). Thus, both FN and CSPG are closely related to preplate cells during the PPZ and CP stages, when both are largely restricted to the layers containing these cells, that is, the preplate itself and the subplate and marginal zones that are formed from it.

\section{Relationship of FN to radial glia during early developmental stages}

In many sections of the early telencephalic wall, the puncta of abFN immunoreactivity appear to be radially aligned, suggesting an association with radial glia. To examine this prospect, we double labeled frozen sections with abFN and RC1 or RC2, monoclonal antibodies that label radial glia of the mouse in sections (Misson et al., 1988; Edwards et al., 1990) and in tissue culture (Culican et al., 1990). Photographic double exposures demonstrate the relationship between abFN labeling and radial glial labeling (Figs. 4, 5). In the VZ stage, punctate abFN labeling is distributed in linear arrays along radial processes labeled with $\mathrm{RC} 1$ or $\mathrm{RC} 2$ and is also prominent around the cells near the ventricular surface (Fig. $4 A$ ). As the shift in abFN labeling takes place with the formation of the preplate zone (Figs. $4 B, 5$ ), the puncta in the preplate continue to correspond to processes labeled with $\mathrm{RC} 1$ or RC2. Puncta of abFN labeling in the subplate after cortical plate formation are also aligned with radial glia (Figs. $4 C, 5$ ). Thus, although the distribution of FN changes in conjunction with the preplate cells during early cortical development as described above, it also maintains a consistent relationship to radial glia.

\section{Tenascin immunolabeling and cortical differentiation}

As the cortical plate reaches maximal thickness, cells of the subplate are clearly demarcated from it and from the underlying intermediate zone by relatively cell-free layers (Fig. 6, CP stagelate). For purposes of description, we have termed these cellfree zones sublaminae $a$ and $c$ of subplate, and the layer containing the subplate cells, sublamina $b$. Sublaminae $a$ and $c$ are rich in CSPG, as is the marginal zone. These layers are also the site of the first detectable labeling with abTEN (Fig. 6, CP stagelate).

The gradual differentiation of cortical plate into cortex begins with the separation of neurons that lie deepest in the cortical plate into distinct laminae. Early lamination is evident in Nisslstained material by the increased distance between differentiating cell nuclei as compared to those in the cortical plate, and the formation of intervening layers that are relatively free of cell bodies (Fig. 6, CTX stage-early). Immunolabeling with abTEN accompanies differentiation, gradually spreading upward as the progressive definition of cortical laminae occurs in

Figure 3. Restriction of FN to preplatc coincides with appearance of early cortical axons demonstrable with abNF labeling: photomicrographic montage and tracing of the cortex in the dorsolateral aspect of the cerebral hemisphere in coronal section at E12. The section was double labeled with abFN (TRITC-tagged second antibody) and abNF (FITC-tagged second antibody). The inset is an outline of the section for orientation. The dorsal surface $(D)$ of the hemisphere is at the top, and the lateral aspect $(L)$ is to the right. Since maturation proceeds from ventrolateral to dorsomedial, the VZ stage is present in the dorsal aspect of the section and the PPZ stage is present in the ventrolateral aspect. Arrows indicate abNF-labeled afferent axons and exactly corresponding points in the abFN-labeled montage. The shift of abFN labeling to a restricted distribution within the preplate and the confinement of early axons to the FN-containing preplate are evident in the tracing, which superimposes the abFN and abNF montages. Intense abFN labeling is also present in association with the pia and blood vessels (shaded areas). Scale bar, $50 \mu \mathrm{m}$. 


\section{A. VZ stage}

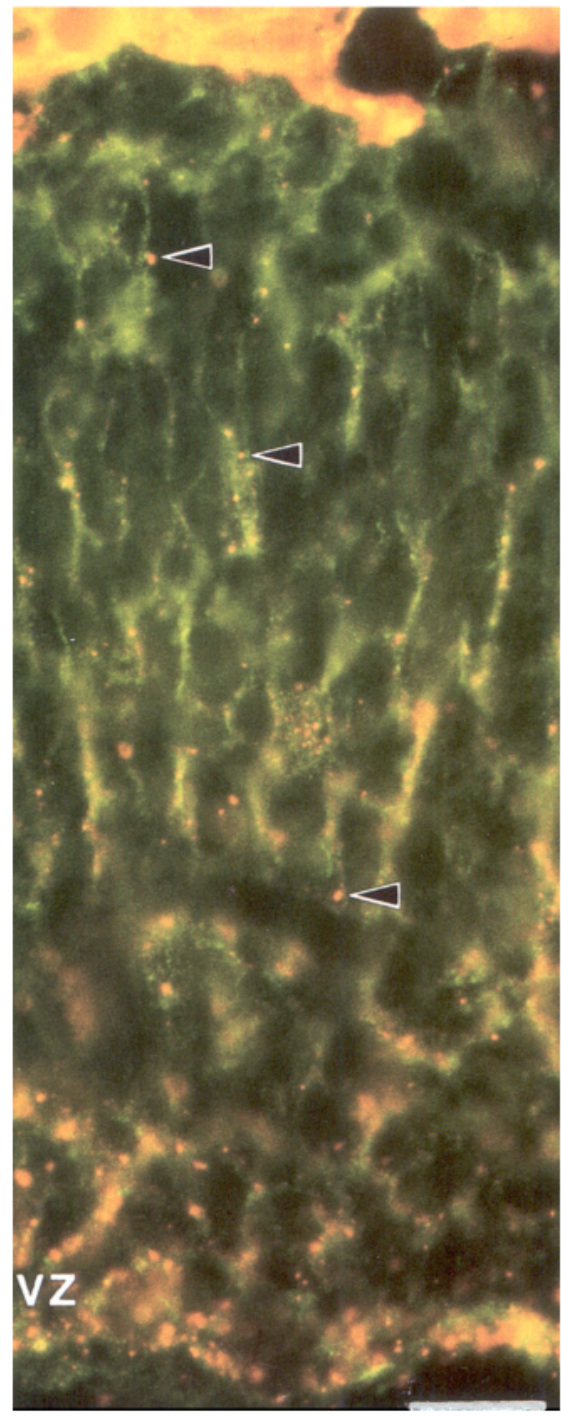

B. PPZ stage

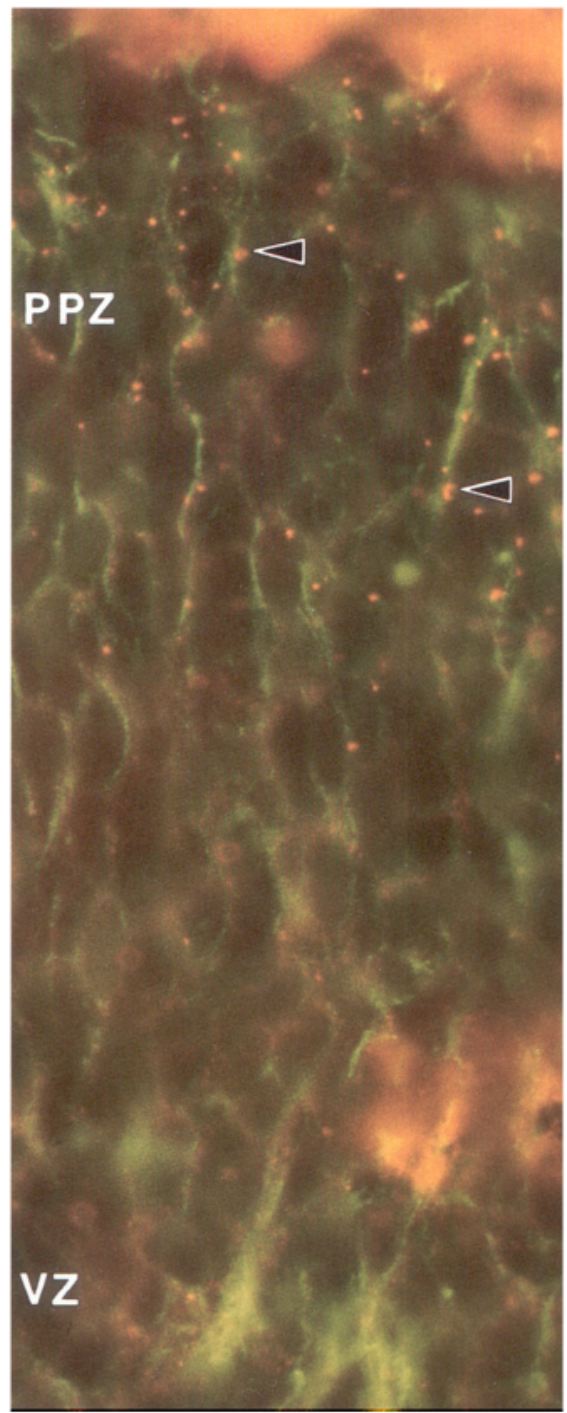

\section{CP stage}

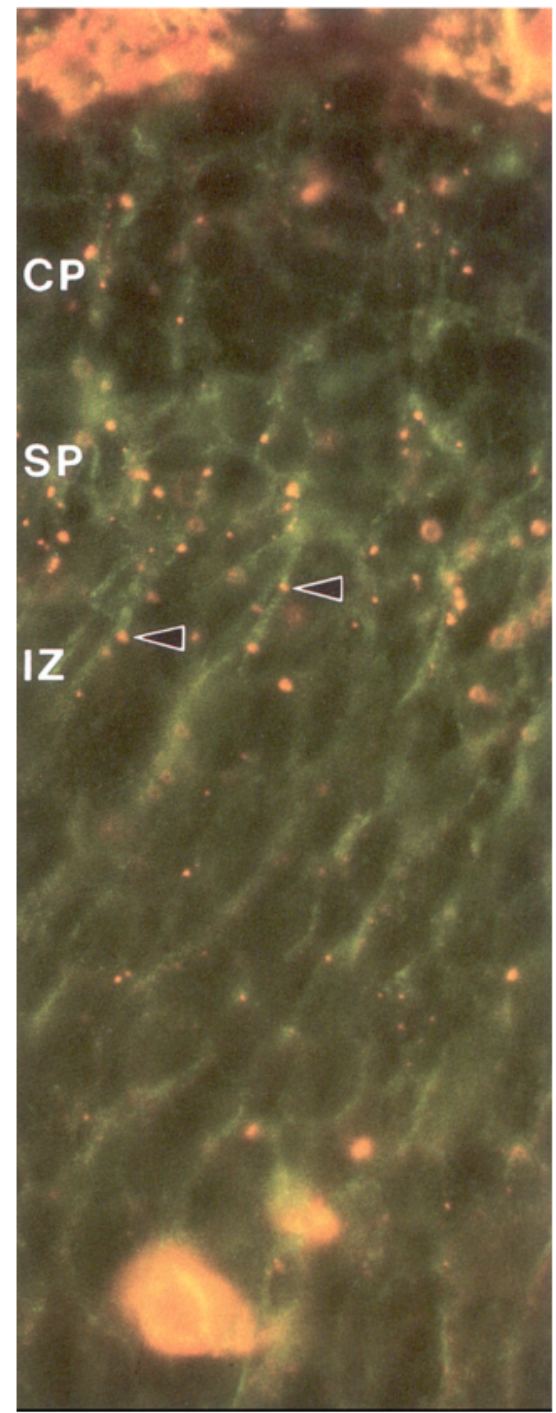

Figure 4. Punctate FN aggregates are distributed along processes of radial glia: immunofluorescent double labeling of coronal sections of the dorsolateral wall of the cerebral hemisphere. Each panel is a photographic double exposure showing labeling of FN with abFN in red-orange (TRITC-tagged second antibody) and labeling of radial glia with RC1 in green (FITC-tagged second antibody). $A$, Ventricular zone (VZ) stage: punctate labeling with abFN (arrowheads) along RC1-labeled radial glia throughout the ventricular zone, and among the cells near the ventricular surface. $B$, Preplate zone ( $P P Z)$ stage: punctate labeling with abFN (arrowheads) is along radial glia, but now primarily in the preplate zone. $C$, Cortical plate $(C P)$ stage: punctate labeling (arrowheads) along radial glia is most prominent in the subplate $(S P)$ and almost completely absent from the cortical plate. IZ, intermediate zone. Intense abFN labeling of the pia is evident at the top of each panel, and blood vessels are immunolabeled in $B$ and $C$. Scale bar, $10 \mu \mathrm{m}$.

inside-out fashion (Fig. 6, CTX stage-early). In contrast, labeling with abCSPG becomes undetectable at the beginning of cortical differentiation (Fig. 6, CTX stage-early). As cortical maturation continues in early postnatal life, the distribution of abTEN labeling spreads to involve all of the cortex and subcortical white matter except the small residual cortical plate where labeling is sparse (Fig. 7, P2). By P4 the cortical plate is no longer evident, and abTEN labeling is present throughout the cortex (Fig. 7, P4). The uniform distribution of abTEN immunolabeling with cortex is disrupted by the formation of the vibrissal barrels (Woolsey and Van der Loos, 1970) in the parietal somatosensory cortex. Immunolabeling is absent from the barrel hollows but remains in the barrel walls (Fig. 7, P7). Immunolabeling has declined substantially throughout the entire cortical wall by P10, when it is seen primarily in association with blood vessels (Fig. 7, P10).

\section{Discussion}

During development of the cerebral cortex of the mouse, the three ECM components we have studied are distributed in distinct temporal and spatial patterns. Prior to preplate formation, immunolabeling for FN and a CSPG is distributed throughout the ventricular zone, with some predominance near the ventricular surface. As newly generated cells leave the ventricular zone to form the preplate, punctate aggregates of $\mathrm{FN}$ associated with radial glia, and a prominent, diffuse accumulation of CSPG 


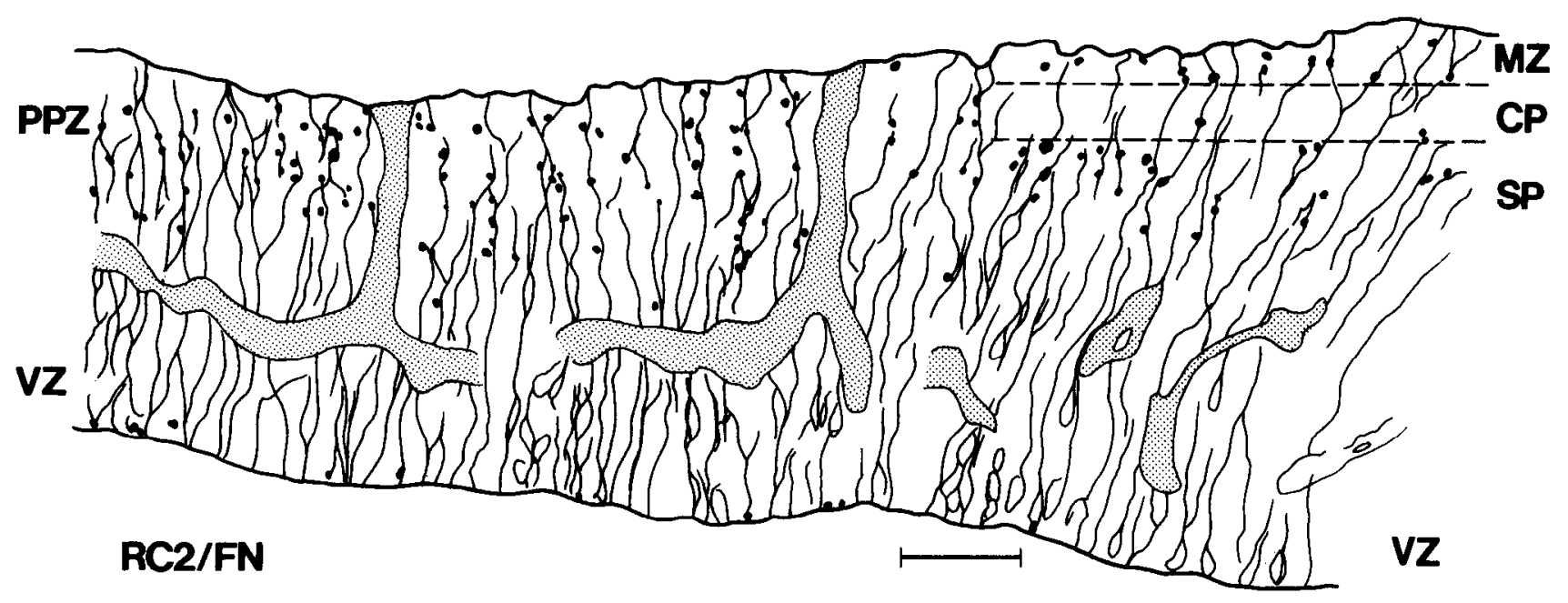

Figure 5. Cortical plate formation divides distribution of FN: tracing of three overlapping photographic double exposures (similar to those shown in Fig. 4) labeled with abFN (black dots) and RC2 (thin lines). Section is from the ventrolateral cortex early on E13 in an area where the cortical plate $(C P)$ is forming in the more mature cortex on the right (between broken lines) and the preplate (PPZ) is undivided in the less mature cortex on the left. FN is present along radial glia in a continuous band in the preplate; after cortical plate formation it is present along radial glia in the subplate $(S P)$ and marginal zone $(M Z)$ but very sparse in the cortical plate. Labeling of the blood vessels by abFN is shown as light shading, labeling associated with the pia-arachnoid has been omitted. Scale bar, $50 \mu \mathrm{m}$.

appear in the preplate. Cortical plate formation within the preplate divides the latter into the marginal zone and subplate, and the distribution of FN and CSPG is similarly divided. Slightly later, as the accumulation of the cortical plate advances, the distribution of $\mathrm{FN}$ in the subplate becomes diffuse rather than punctate (Stewart and Pearlman, 1987). Immunolabeling for tenascin appears late in the $\mathrm{CP}$ stage, at a time when labeling for FN has all but disappeared and labeling of CSPG is declining rapidly. It is detectable first in the subplate and marginal zone, then gradually appears in all cortical layers as they differentiate, and in the subcortical white matter. As the barrel field forms in the somatosensory cortex, tenascin immunolabeling is excluded from the relatively cell-free hollows of the barrels. Immunolabeling for tenascin declines rapidly during the second postnatal week.

\section{The redistribution of $F N$ and $C S P G$ during early cortical} development: association with preplate cells and radial glia

Our observations indicate that the laminar distribution of FNand CSPG-like immunoreactivity in early cortical development is related to the distribution of preplate cells and that punctate abFN labeling is also closely associated with radial glia.

Both preplate cells and radial glia are only transiently present during cortical formation. Radial glia appear to guide migrating neurons from the ventricular zone to the cortical plate (Ramon y Cajal, 1891; Rakic, 1972) and are then transformed into astrocytes (Ramon y Cajal, 1911; Schmechel and Rakic, 1979; Levitt et al., 1981; Pixley and de Vellis, 1984; Voigt, 1989; Culican et al., 1990). Preplate cells are the first postmitotic cells to leave the proliferative zone. Many are clearly neurons since they form synapses, contain neuropeptides, are labeled by antibodies to a neuronal microtubule-associated protein (MAP2; Chun and Shatz, 1989), and extend the first axons to leave the cortex (McConnell et al., 1989; De Carlos and O'Leary, 1990; Bicknese et al., 1991). Some preplate cells may be glia, since they have distinct glia-like end feet in contact with the pial basement membrane; cells with this characteristic are later pos- itive for glial fibrillary acidic protein (Rickmann and Wolff, 1985; Choi, 1988). The cortical plate, which will form definitive cortex, is assembled within the layer of preplate cells and the early axons that course among them (Marin-Padilla, 1978). Somc preplate neurons will survive as the Cajal-Retzius cells of the molecular layer and as interstitial neurons in the subcortical white matter (Kostovic and Rakic, 1980; Luskin and Shatz, 1985; Valverde and Facal-Valverde, 1987; Al-Ghoul and Miller, 1989; Valverde et al., 1989); a large proportion are lost in both the cat and the rodent (Luskin and Shatz, 1985; Woo et al., 1990). The presumptive preplate glia appear to proliferate to produce astrocytes and perhaps other glial types as well (Rickmann and Wolff, 1985).

The close association of immunolabeling for both FN and CSPG with preplate cells and for FN with radial glia suggests that one or both of these cell types are producing FN and CSPG, or are responsible for their local accumulation. Destruction of subplate neurons with excitotoxins results in marked local diminution of FN, supporting the concept that FN and subplate cells are closely associated (Chun and Shatz, 1988). However, the transient nature of both radial glia and preplate cells does not directly account for the transient presence of FN and CSPG. Immunoreactivity for FN becomes virtually undetectable in the mouse by E16-18 and for CSPG by E1 8, whereas the transformation of radial glia to astrocytes takes place largely between E17 and P2 (Takahashi et al., 1990) and preplate cells are lost even later (Luskin and Shatz, 1985; Woo et al., 1990). Whether the decline in immunolabeling for FN and CSPG is caused by reduced synthesis and deposition or by enhanced degradation (Emonard and Grimaud, 1990) remains to be determined.

\section{Hypotheses for the roles of ECM in early cortical development}

As discussed previously (Stewart and Pearlman, 1987), no matter what roles FN and CSPG play in early cortical development, they are probably doing so in conjunction with other ECM components, since several have been described with a similar distribution. These include undefined glycosaminoglycans la- 


\section{abCSPG}
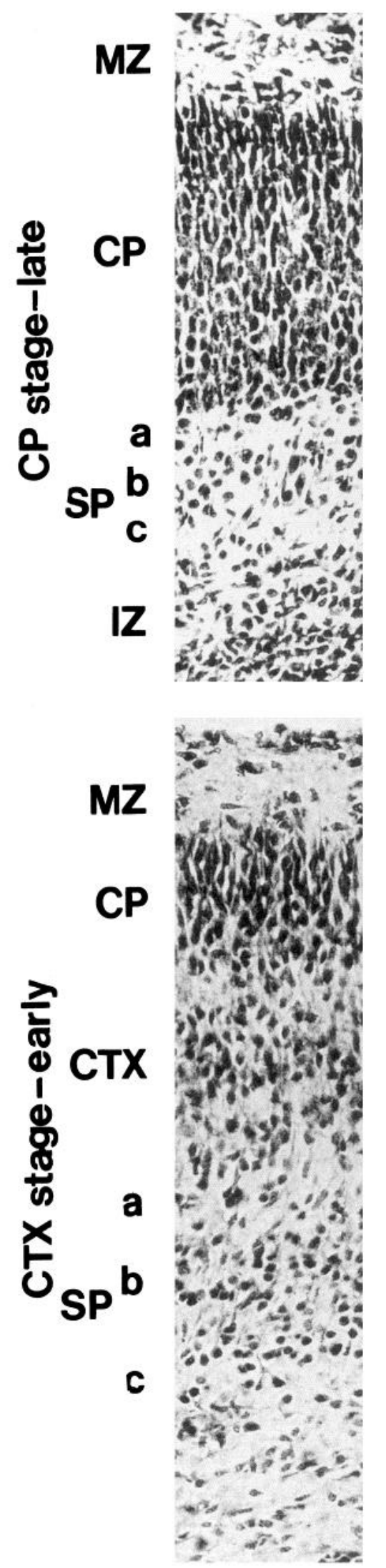

\section{abTEN}
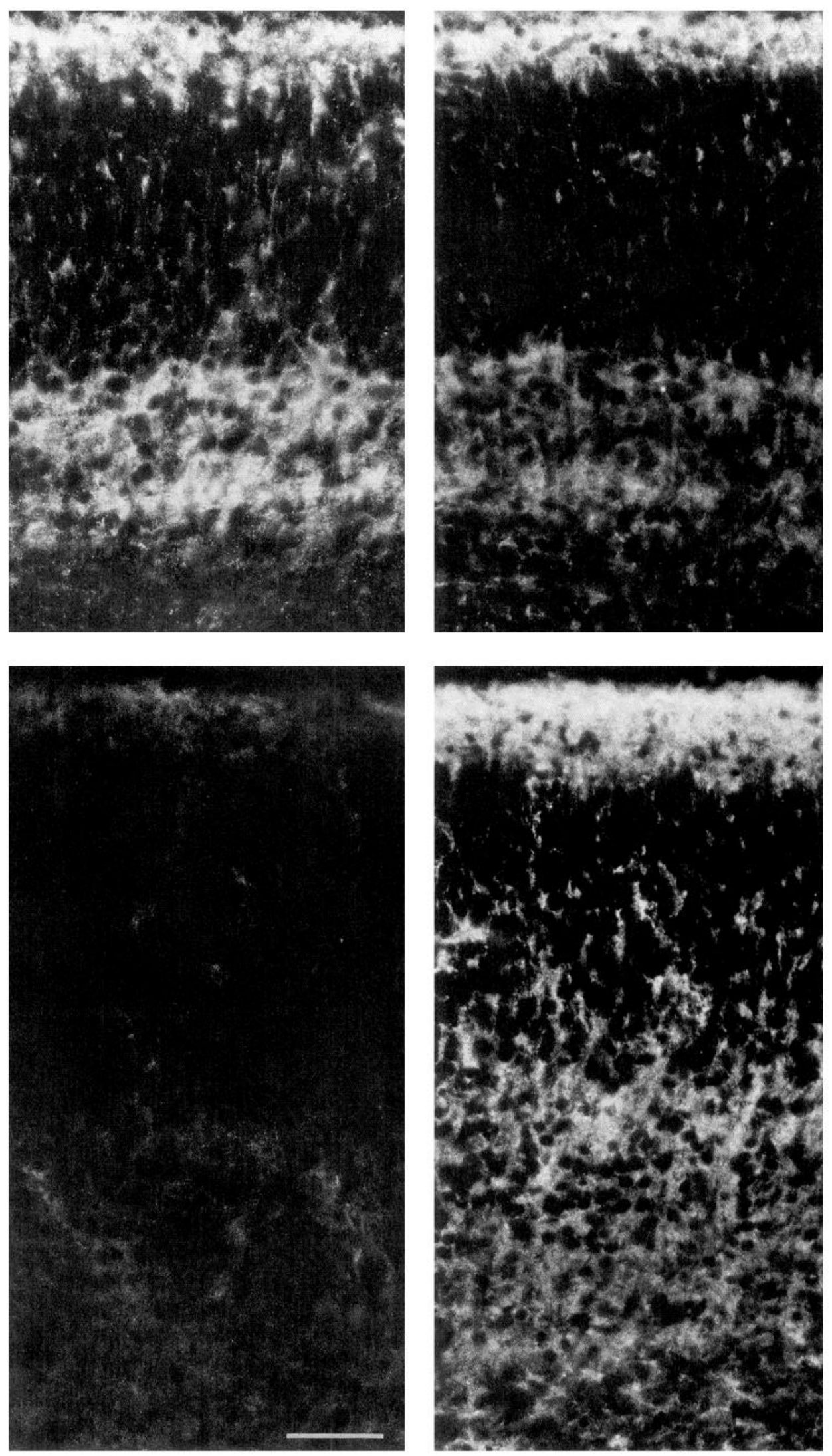
beled in the preplate, marginal zones, and subplate with colloidal iron and alcian blue (Derer and Nakanishi, 1983; Nakanishi, 1983), and in the subplate and marginal zones with lectins (Bruckner et al., 1985). Hyaluronectin is demonstrable with antibodies in a similar distribution in the rat (Delpech and Delpech, 1984; Bignami and Delpech, 1985). ECM is evident by electron microscopy in the subplate and marginal zones (Derer and Nakanishi, 1983; Hankin and Silver, 1988). These studies have emphasized the association of ECM with either neurons (Derer and Nakanishi, 1983; Nakanishi, 1983) or astrocytes and microglia (Bruckner et al., 1985). An association of ECM with radial glia was suggested by the observation of punctate immunoreactivity for laminin, but not FN, in linear arrays in cerebral hemispheres, diencephalon, and mesencephalon, and along Bergmann glia in the cerebellum (Liesi, 1985). It remains to be determined whether laminin undergoes a redistribution in cortex similar to that which we found for FN; although we have used several monoclonal and polyclonal antibodies to laminin, we have found only faint punctate accumulations of immunoreactivity with a distribution that is approximately similar to that of FN (data not shown). In other sites where punctate aggregates of FN immunoreactivity are present, such as the migratory pathway of neural crest cells (Brauer and Markwald, 1988) and the devcloping heart (Mjaatvedt et al., 1987), FN is thought to be a central constituent of complexes that contain other ECM components.

$E C M$ in neurite outgrowth. The suggestion that ECM serves as a guide for axonal extension (Stewart and Pearlman, 1987; Chun and Shatz, 1988; Letourneau et al., 1988) has been prominent in most of the reports on ECM distribution in developing cortex, primarily because early neuronal processes uccupy the preplate, marginal zones, and subplate (Marin-Padilla, 1978; Schlumpf et al., 1980; Caviness and Korde, 1981; Lidov and Molliver, 1982; Verney et al., 1982; Crandall and Caviness, 1984; McConnell et al., 1989) where ECM is prominent. The importance of ECM components in neurite outgrowth has been underlined by numerous studies of central and peripheral neurons in tissue culture (Hauschka and Ose, 1979; Akers et al., 1981; Manthorpe et al., 1983; Rogers et al., 1983, 1987; Liesi ct al., 1984; Smallheiscr et al., 1984; Adler et al., 1985; Hammarback et al., 1985; Neugebauer et al., 1988; Tomaselli and Reichardt, 1988; Tomaselli et al., 1988; Humphries et al., 1989; Reichardt and Tomaselli, 1991).

Our observation that the shift of FN to the preplate takes place just before the first neuronal processes are demonstrable in that layer with neurofilament antibodies lends support to the idea that ECM is involved in defining a terrain for process extension. Whether the neuronal processes in the preplate are afferent axons, as suggested by Golgi studies (Marin-Padilla, 1978), or local and efferent processes of preplate-subplate cells, as indicated by fluorescent tracers at slightly later stages (McConnell et al., 1989; De Carlos and O'Leary, 1990), remains to be determined. In two other axon tracts of the CNS, laminin, but not FN, is present in punctate arrays during early axonal elongation (Letourneau et al., 1988; Liesi and Silver, 1988). In these studies and in ours, antibodies to neurofilaments were used to identify axons. Since the expression of the neurofilament proteins recognized by these antibodies may not be completely synchronous with axonal elongation in very immature axons, these studies provide only a close approximation of the time of axonal extension.

In contrast to our finding that a CSPG is prominent in preplate-derived layers that contain numerous extending axons (Crandall and Caviness, 1984), sulfated glycosaminoglycans have been implicated in establishing barriers to axon outgrowth in other sites. Keratin sulfate is present in association with the glial cells of the roof plate in the spinal cord of the chick and in the midline of the optic tectum of the hamster (Snow et al., 1990b). Axons growing near these areas do not invade them even though they contain ample extracellular space, suggesting that keratin sulfate, and perhaps other glycosaminoglycans, may inhibit axonal extension (Snow et al., 1990b). Similarly, the posterior sclerotome, which is avoided by the growing axons of spinal motor neurons, contains high levels of glycosaminoglycans (Tosney and Landmesser, 1985). In tissue culture, processes of chick dorsal root ganglia grow extensively on stripes of laminin, but avoid adjacent stripes coated with keratin sulfate/CSPG (Snow et al., 1990a). Heparin and hyaluronic acid are also inhibitory to neurite outgrowth from these cells (Carbonetto et al., 1983), and chondroitin sulfates inhibit neurite outgrowth from $\mathrm{PC} 12$ cells (Oohira et al., 1991).

The apparent conflict between our observations and those that suggest that proteoglycans serve as barriers to axonal outgrowth (Snow el al., 1990a,b) may be a manifestation of the diversity of proteoglycans. There is a wide variety of proteoglycan core proteins with varying amounts of one or more types of glycosaminoglycan attached (Gallagher, 1989). Furthermore, a single class of glycosaminoglycan is not homogeneous; chondroitin sulfates, for example, may vary in molecular mass from 5 to $50 \mathrm{kDa}$ depending on the number of disaccharides in the polymer chain, and the number of sulfates per disaccharide unit is also variable. Proteoglycans also vary considerably in function. Various ECM proteoglycans have been shown to either support, hinder, or block completely the binding of cell surface integrins to other ECM components, and to bind directly to nonintegrin cell surface ligands (Gallagher, 1989). Cell surface proteoglycans may also mediate interactions with ligands on other cells, as in the binding of the cytotactin-binding proteoglycan of neurons with cytotactin of glia (Hoffman and Edelman, 1987). Thus, differences in proteoglycan structure may make them intrinsically more or less attractive to growing axons (Oohira et al., 1991). Alternatively, it has been suggested that proteoglycans may bind varying amounts of other matrix components such as FN laminin, which would produce differences in their ability to support neurite outgrowth (Snow et al., 1990a). Our findings suggest that the CSPG demonstrable with the an-

\footnotetext{
Figure 6. Immunoreactivity for CSPG declines and tenascin appears as early cortical differentiation begins: immunofluorescent double labeling of coronal sections of the cerebral hemisphere with abCSPG (TRITC-tagged second antibody) and abTEN (FITC-tagged second antibody). The panel at the left shows the same area in an adjacent section stained with cresyl violet. Cortical plate (CP) stage-late, abCSPG labeling is prominent in the marginal zone (MZ) and subplate (SP) as abTEN labeling first appears in these zones. The subplate cells form a distinct cell-dense layer $(S P b)$ between two cell-sparse layers that are rich in ECM $(S P a$ and $S P c)$. IZ, intermediate zone. Cortex $(C T X)$ stage-early, Immunolabeling for tenascin accompanies delineation and differentiation of deep cortical layers and remains sparse in the less mature cortical plate. Immunolabeling for CSPG becomes undetectable. Scale bar, $10 \mu \mathrm{m}$.
} 

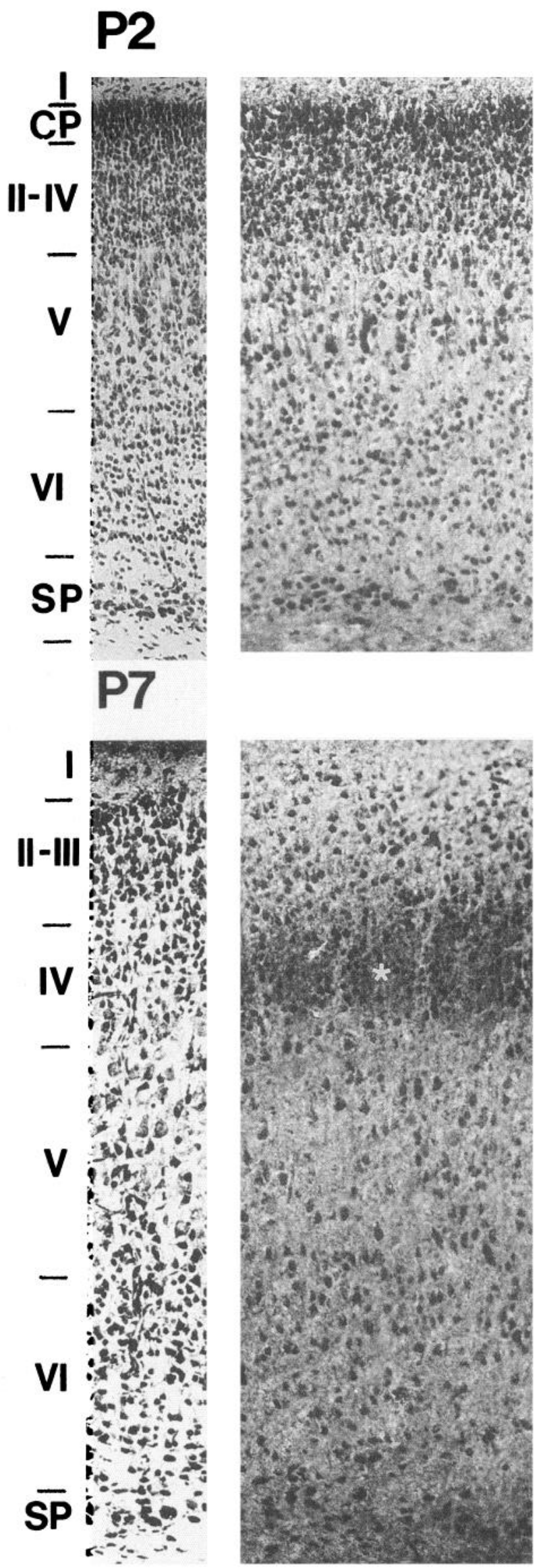

P4
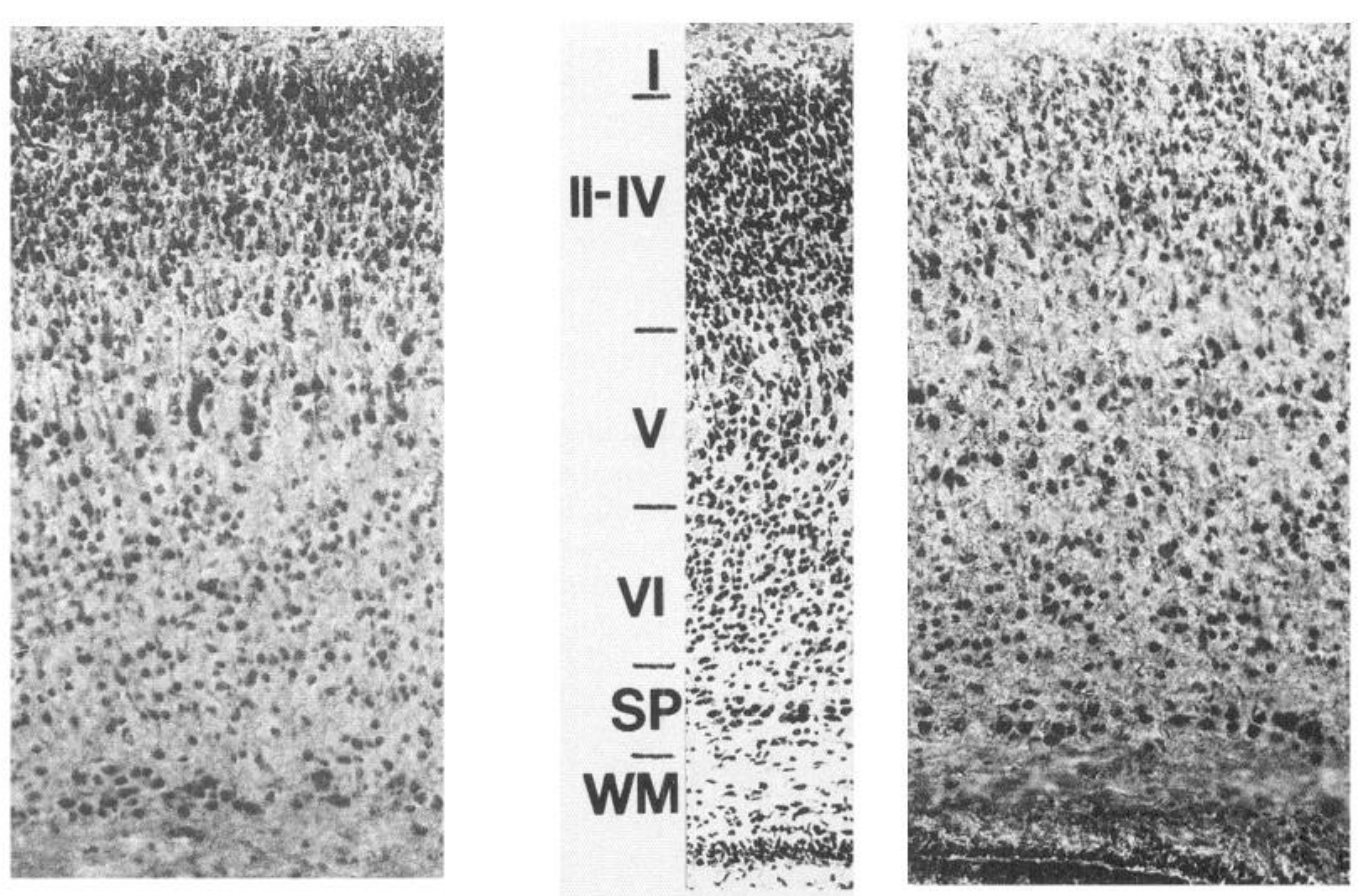

WM

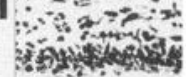

PIO
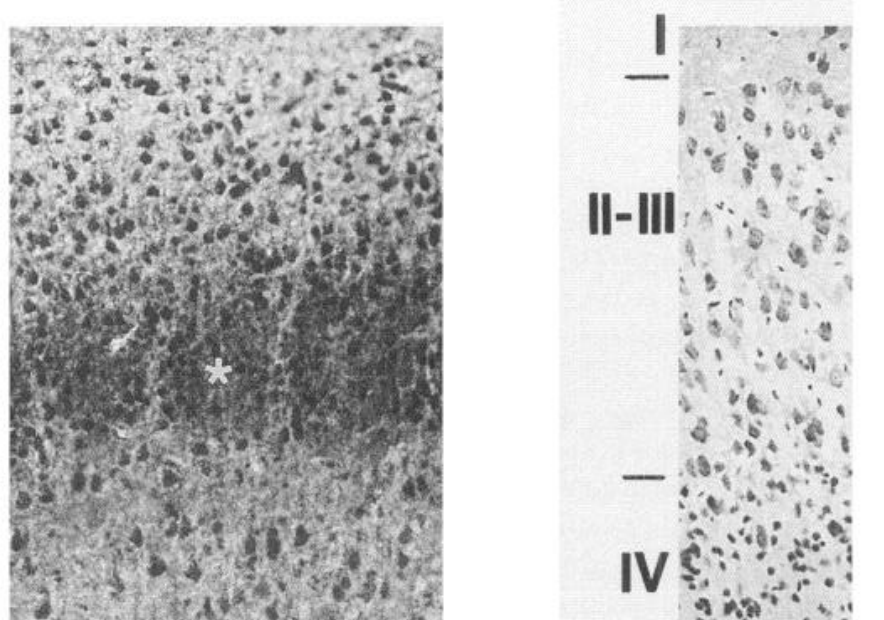

||-III

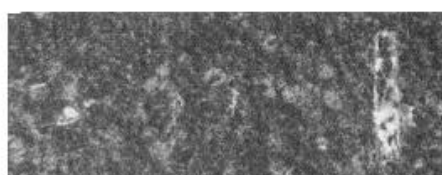

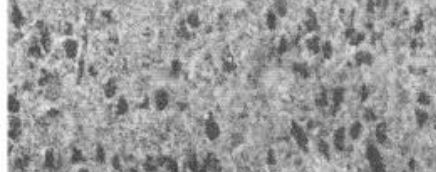
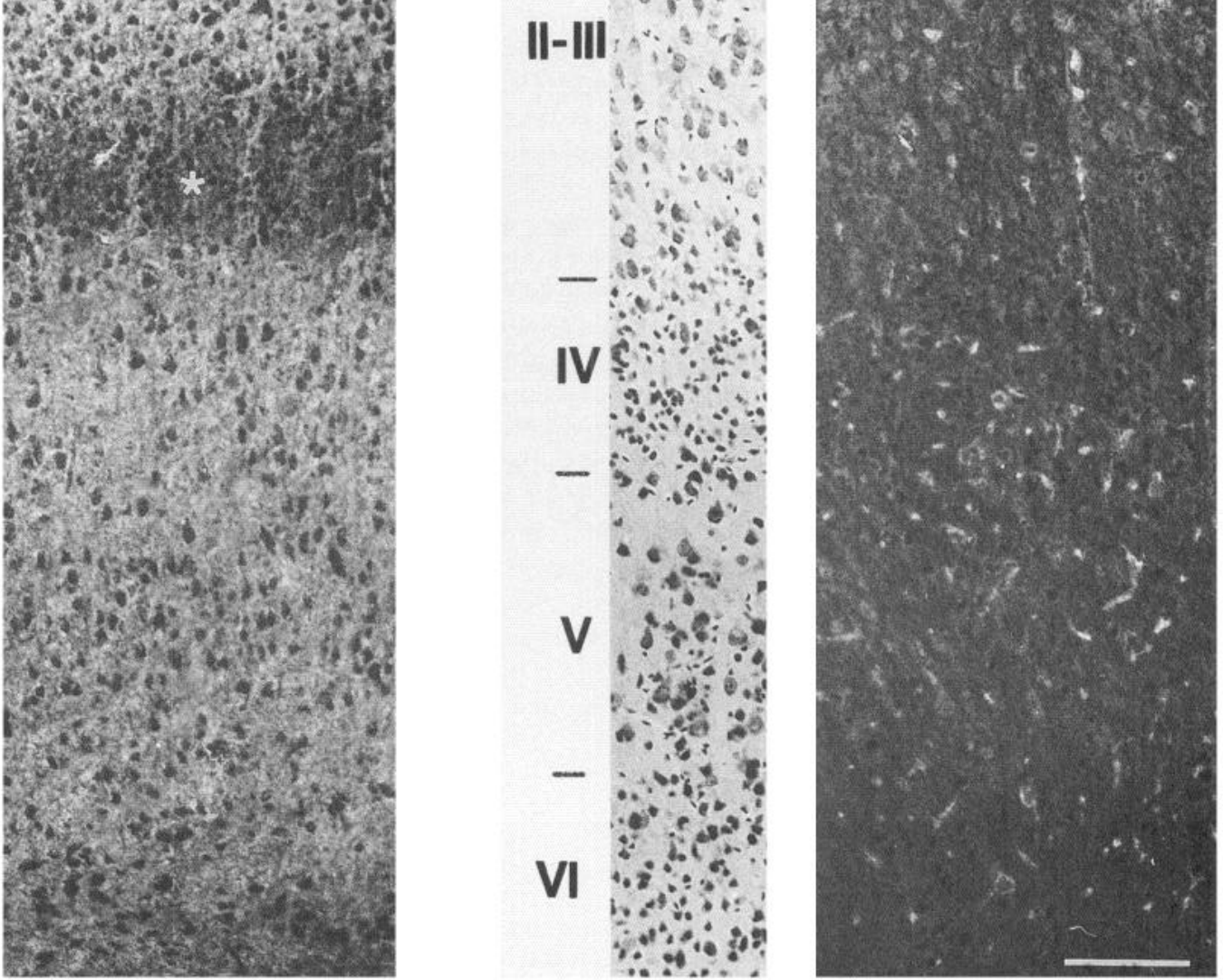
tibody we have used (Avnur and Geiger, 1984) does not have an inhibitory or barrier role; additional analysis will be required to determine which of the many proteoglycans present in developing brain (Oohira et al., 1988; Margolis and Margolis, 1989; Herndon and Lander, 1990) this antibody labels.

ECM in neuronal migration. The second major set of hypotheses regarding the role of ECM implicates matrices in the migration of neurons from the ventricular zone to the cortical plate along radial glia (Liesi, 1985), or in the formation of the cortical plate at the end of that migration (Stewart and Pearlman, 1987; Chun and Shatz, 1988). The shift in distribution of FN and CSPG takes place in conjunction with the migration of preplate cells. It has been suggested that FN may be responsible for holding preplate cells in the ventricular zone (Stallcup et al., 1989); its loss there may allow them to move into the preplate zone either by nuclear translocation and process retraction (Morest, 1970) or by migration along radial glia (Rakic, 1972). Since the shift in distribution of FN and CSPG takes place before the migration of the first cortical plate neurons, it is not likely that they serve as a substrate for this migration. As we suggested earlier (Stewart and Pearlman, 1987), ECM is appropriately located to offer a signal to arriving neurons that they are approaching the end of their journey. To extend this hypothesis, we suggest that radial glia, preplate cells, and the ECM might constitute a framework for subsequent cortical plate formation. Cortical plate neurons would invade that framework and establish residence within it; radial glia would continue to elongate as the cortical plate expands, but the former preplate cells, now located above and below the cortical plate, would maintain their relative positions, held in place by FN, CSPG, and other ECM components, and perhaps by ECM-mediated connections to the radial glia.

\section{Role of tenascin in late cortical development}

A role in neuronal migration has been suggested for tenascin (cytotactin) because of its distribution in the developing cerebellum and the ability of anti-cytotactin antibodies to block granule cell migration partially in cerebellar slices (Crossin et al., 1989). However, tenascin immunolabeling appears late in development relative to the migration of most cortical neurons (Godfraind et al., 1988; Crossin et al., 1989; present study). At E16 in the mouse, when we first detect immunolabeling in the subplate and marginal zone, the cortical plate has already reached maximal thickness. Even though more neurons will be added to the top of the cortical plate as those at the base mature, the neurons that comprise the cortical plate at this stage have already completed their migration, suggesting that tenascin docs not have a role in the migration of a large proportion of cortical neurons, nor does the distribution of immunolabeling for tenascin correlate either spatially or temporally with the establishment of the major efferent or afferent cortical pathways. Efferents from preplate neurons are evident in the intermediate zone of both rat and mouse in the preplate stage (De Carlos and
O'Leary, 1990; Bicknese et al., 1991). Efferents from cortical neurons are demonstrable very soon after the cortical plate is formed; afferents from the thalamus are demonstrable 12-24 hr later (De Carlos and O'Leary, 1990; Reinoso and O'Leary, 1990; Bicknese et al., 1991). In contrast, immunolabeling for tenascin is not evident in the subplate until approximately $72 \mathrm{hr}$ after cortical plate formation (present study). Immunolabeling for tenascin subsequently appears in both the differentiating cortex and the subcortical white matter; the latter contains numerous axonal processes that are already well established. The suggestion that tenascin $(\mathrm{J} 1)$ is providing a barrier to neurite outgrowth (Steindler et al., 1989, 1990; Faissner and Kruse, 1990) may hold for the processes growing within the hollows of cortical vibrissal barriers, but appears not to be the case for the remainder of differentiating cortex where tenascin expression is diffuse in locations where growth of axons and dendrites is extensive. Most recent evidence indicates that the restriction of labeling for tenascin and other glycoconjugates to the barrel walls is actually dependent on the prior formation of a barrel pattern by thalamic afferents (Christensen et al., 1990; Schlagger and O'Leary, 1990, 1991; Jhaveri et al., 1991).

Several lines of evidence suggest that tenascin is closely associated with glia. It is synthesized by glia in culture (Grumet et al., 1985; Hoffman et al., 1988; Crossin et al., 1989), associated predominantly with glial membranes by electron microscopy (Steindler et al., 1989), and prominent in the walts of cortical barrels that contain astrocytes demonstrable with antibodies to glial fibrillary acidic protein (Steindler et al., 1989). From this evidence, we suggest that immunolabeling for tenascin in cortex represents the expression of the molecule on the surface of developing glial cells or in their pericellular environment. The expression occurs first in marginal zone and subplate, the most mature of the layers, at the time when definitive astrocytes are evident in these layers (E16-17; Rickmann and Wolff, 1985). Extension of tenascin expression into the cortical plate as it matures from deep layers to superficial, and in the subcortical white matter, corresponds exactly to the time (E17 to P2) when extensively branched astrocytes become apparent in these layers, many as the result of transformation of radial glia to astrocytes (Rickman and Wolff, 1985; Takahashi et al., 1990). Thus, the developmental event that correlates best with the expression of tenascin is the extensive outgrowth of glial processes that occurs with early cortical maturation. Its expression does not appear to be related to either the neuronal migration that establishes the preplate and cortical plate or the axonal extensions that establish major axonal pathways.

\section{References}

Adler R, Jerdan J, Hewitt AT (1985) Responses of cultured neural retinal cells to substratum-bound laminin and other extracellular matrix molecules. Dev Biol 112:100-114.

Akers RM, Moshier DF, Lilien JE (1981) Promotion of retinal neurite outgrowth by substratum-bound fibronectin. Dev Biol 86:179-188.

Al-Ghoul WM, Miller MW (1989) Transient expression of Alz-50

Figure 7. Transient immunolabeling for tenascin during postnatal cortical maturation: immunofluorescent labeling of coronal sections of the cerebral cortex on P2-10 with abTEN. At each age the panel on the left shows the same area in an adjacent section stained with cresyl violet. $P 2$, Immunolabeling is present throughout the cortex but is sparse in the small, densely packed residual cortical plate $(C P)$. $P 4$, Cortical plate is no longer evident; immunolabeling is present throughout cortex. P7, Parietal cortex, barrel field. Immunolabeling is absent from the barrel hollows $\left.{ }^{*}\right)$, present in the barrel wall and in the remainder of cortex, but declining in lower layers. P10. Immunolabeling is nearly undetectable except in association with blood vessels. I-VI, layers I-VI; $S P$, subplate; $W M$, white matter. Scale bar, $20 \mu \mathrm{m}$. 
immunoreactivity in developing rat neocortex: a marker for naturally occurring neuronal death? Brain Res 481:361-367.

Angevine JB Jr, Sidman RL (1961) Autoradiographic study of cell migration during histogenesis of cerebral cortex in the mouse. Nature 192:766-768.

Aquino DA, Margolis RU, Margolis RK (1984) Immunocytochemical localization of a chondroitin sulfate proteoglycan in nervous tissue. II. Studies in developing brain. J Cell Biol 99:1130-1139.

Avnur Z, Geiger B (1984) Immunocytochemical localization of native chondroitin-sulfate in tissues and cultured cells using specific monoclonal antibody. Cell 38:811-822.

Bicknese AR, Sheppard AM, O'Leary DDM, Pearlman AL (1991) Thalamocortical axons preferentially extend along a chondroitin sulfate proteoglycan enriched pathway coincident with the neocortical subplate and distinct from the efferent path. Soc Neurosci Abstr 17: 764.

Bignami A, Delpech B (1985) Extracellular matrix glycoprotein (hyaluronectin) in early cerebral development. Int J Dev Neurosci 3: 301-307.

Boucaut JC, Darribere T, Boulekbache H, Thiery J-P (1984) Prevention of gastrulation but not neurulation by antibodies to fibronectin in amphibian embryos. Nature 307:364-366.

Bourdon MA, Wikstrand CJ, Furthmayer H, Matthews TJ, Bigner DD (1983) Human glioma-mesenchymal extracellular matrix antigen defined by monoclonal antibody. Cancer Res 43:2796-2805.

Brauer PR, Markwald RR (1988) Specific configurations of fibronectin-containing particles correlate with pathways taken by neural crest cells at two axial levels. Anat $\operatorname{Rec} 222: 69-82$.

Bronner-Fraser M (1986) An antibody to a receptor for fibronectin and laminin perturbs cranial neural crest development in vivo. Dev Biol 117:528-536.

Bronner-Fraser M (1988) Distribution and function of tenascin during cranial neural crest development in the chick. J Neurosci Res 21: 135-147.

Bruckner G, Muller L, Wollweber L, Samtleben R, Biesold D (1985) Lectin binding sites and anionic components related to differentiation in the prenatal rat cerebral cortex. J Hirnforsch 6:615-634.

Carbonetto S, Gruver MM, Turner DC (1983) Nerve fiber growth in culture on fibronectin, collagen, and glycosaminoglycan substrates. J Neurosci 3:2324-2335.

Caviness VS Jr, Korde MG (1981) Monoaminergic afferents to the neocortex: a developmental histofiuorescence study in normal and reeler mouse embryos. Brain Res 209:1-9.

Chiquet M (1989) Tenascin/J1/cytotactin: the potential function of hexabrachion proteins in neural development. Dev Neurosci 11:266275.

Chiquet M, Fambrough DM (1984) Chick myotendinous antigen II: a novel extracellular glycoprotein complex consisting of large disulfide-linked subunits. J Cell Biol 98:1937-1946.

Choi BH (1988) Prenatal gliogenesis in the developing cerebrum of the mouse. Glia 1:308-316.

Christensen JJ, Bennett-Clarke CA, Woolsey TA, Rhoades RW (1990) Developing barrel patterns shown by serotonin, lectin and cytochrome oxidase in mice. Soc Neurosci Abstr 16:631.

Chun JJM, Shatz CJ (1988) A fibronectin-like molecule is present in the developing cat cerebral cortex and is correlated with subplate neurons. J Cell Biol 106:857-872.

Chun JJM, Shatz CJ (1989) The earliest-generated neurons of the cat cerebral cortex: characterization by MAP2 and neurotransmitter immunohistochemistry during fetal life. J Neurosci 9:1648-1667.

Chuong C-M, Crossin KL, Edelman GM (1987) Sequential expression and differential function of multiple adhesion molecules during the formation of cerehellar cortical layers. J Cell Biol 104:331-342.

Crandall JE, Caviness VS Jr (1984) Axon strata of the cerebral wall in embryonic mice. Dev Brain Res 14:185-195.

Crossin KL, Hoffman S, Tan S-S, Edelman GM (1989) Cytotactin and its proteoglycan ligand mark structural and functional boundaries in somatosensory cortex of the early postnatal mouse. Dev Biol 136: 381-391.

Culican SM, Baumrind NL, Yamamoto M, Pearlman AL (1990) Cortical radial glia: identification in tissue culture and evidence for their transformation to astrocytes. J Neurosci 10:684-692.

De Carlos JA, O'Leary DDM (1990) Subplate neurons "pioneer" the output pathway of rat cortex but not pathways to brainstem or spinal targets. Soc Neurosci Abstr 16:311.

Delpech A, Delpech B (1984) Expression of hyaluronic acid-binding glycoprotein, hyaluronectin, in the developing rat embryo. Dev Biol 101:391-400.

Derer P, Nakanishi S (1983) Extracellular matrix distribution during neocortical wall ontogenesis in "normal" and "reeler" mice. J Hirnforsch 24:209-224.

Donovan PJ, Stott D, Godin I, Heasman J, Wylie CC (1987) Studies on the migration of mouse germ cells. J Cell Sci [Suppl] 8:359-367.

Duband JL, Rocher S, Chen WT, Yamada KM, Thiery JP (1986) Cell adhesion and migration in the early vertebrate embryo: location and possible role of the putative fibronectin receptor complex. J Cell Biol 102:160-178.

Edwards MA, Yamamoto M, Caviness VS Jr (1990) Organization of radial glia and related cells in the developing murine CNS. An analysis based upon a new monoclonal antibody marker. Neuroscience 36: 121-144.

Emonard H, Grimaud J-A (1990) Matrix metalloproteinases. A review. Cell Mol Biol 36:131-153.

Erickson HP, Bourdon MA (1989) Tenascin: an extracellular matrix protein prominent in specialized embryonic tissues and tumors. Annu Rev Cell Biol 5:71-92.

Erickson HP, Iglesias IL (1984) A six-armed oligomer isolated from cell surface fibronectin preparations. Nature 311:267-269.

Faissner A, Kruse J (1990) J1/tenascin is a repulsive substrate for central nervous system neurons. Neuron 5:627-637.

Gallagher JT (1989) The extended family of proteoglycans: social residents of the pericellular zone. Curr Opin Cell Biol 1:1201-1218.

Godfraind C, Schachner M, Goffinet AM (1988) Immunohistological localization of cell adhesion molecules L1, J1, N-CAM and their common carbohydrate L2 in the embryonic cortex of normal and reeler mice. Dev Brain Res 42:99-111.

Grumet M, Hoffman S, Crossin KL, Edelman GM (1985) Cytotactin, an extracellular matrix protein of neural and non-neural tissues that mediates glia-neuron interaction. Proc Natl Acad Sci USA 82:80758079.

Hagg T, Muir D, Engvall E, Varon S, Manthorpe M (1989) Lamininlike antigen in rat CNS neurons: distribution and changes upon brain injury and nerve growth factor treatment. Neuron 3:721-732.

Hammarback JA, Palm SL, Furcht L, Letourneau PC (1985) Guidance of neurite outgrowth by pathways of substratum-adsorbed laminin. J Neurosci Res 13:213-220.

Hankin MH, Silver J (1988) Development of intersecting CNS fiber tracts: the corpus callosum and its perforating fiber pathway. J Comp Neurol 272:177-190.

Hatten ME, Furie MB, Rifkin DB (1982) Binding of developing mouse cerebellar cells to fibronectin: a possible mechanism for the formation of the external granular layer. J Neurosci 2:1 195-1206.

Hauschka SD, Ose M (1979) In vitro requirements for neural retina ganglion cell axon formation. In Vitro 15:204.

Herndon ME, Lander AD (1990) A diverse set of developmentally regulated proteoglycans is expressed in the rat central nervous system. Neuron 4:949-961.

Hoffman S, Edelman GM (1987) A proteoglycan with HNK-1 antigenic determinants is a neuron associated ligand for cytotactin. Proc Natl Acad Sci USA 84:2523-2527.

Hoffman S, Crossin KL, Edelman GM (1988) Molecular forms, binding functions and developmental expression patterns of cytotactin and CTB proteoglycan, an interactive pair of extracellular matrix molecules. J Cell Biol 106:519-532.

Humphries MJ, Akiyama SK, Komoriya A, Olden K, Yamada KM (1989) Neurite extension of chicken peripheral nervous system neurons on fibronectin: relative importance of specific adhesion sites in the central cell-binding domain and the alternatively-spliced type III connecting segment. J Cell Biol 106:1289-1297.

Hynes RO (1990) Fibronectins. New York: Springer.

Jhaveri S, Erzurumlu RS, Crossin K (1991) Barrel construction in rodent neocortex: role of thalamic afferents versus extracellular matrix molecules. Proc Natl Acad Sci USA 88:4489-4493.

Johnson GD, Nogueira-Araujo GM (1981) A simple method of reducing the fading of immunofluorescence during microscopy. J Immunol Methods 43:349-350.

Kostovic I, Rakic P (1980) Cytology and time of origin of interstitial neurons in the white matter in infant and adult human and monkey telencephalon. J Neurocytol 9:219-242.

Krayanek S (1980) Structure and orientation of extracellular matrix in developing chick optic tectum. Anat Rec 197:95-109.

Kruse J, Keilhauer G, Faissner A, Timpl R, Schachner M (1985) The 
J1 glycoprotein - a novel nervous system cell adhesion molecule of the L2/HNK-1 family. Nature 316:146-148.

Letourneau PC, Madsen AM, Palm SL, Furcht LT (1988) Immunoreactivity for laminin in the developing ventral longitudinal pathway of the brain. Dev Biol 125:135-144.

Levitt P, Cooper ML, Rakic P (1981) Coexistence of neuronal and glial precursor cells in the cerebral ventricular zone of the fetal monkey: an ultrastructural immunoperoxidase analysis. J Neurosci 1:2739.

Lidov HG, Molliver ME (1982) Immunohistochemical study of the development of serotonergic neurons in the rat CNS. Brain Res Bull 9:559-604.

Liesi $P$ (1985) Do neurons in the vertebrate CNS migrate on laminin? EMBO J 4:1163-1170.

Liesi P, Silver J (1988) Is astrocyte laminin involved in axon guidance in the mammalian CNS? Dev Biol 130:744-785.

Liesi P, Dahl D, Vaheri A (1984) Neurons cultured from developing rat brain attach and spread preferentially to laminin. J Neurosci Res $11: 241-251$.

Luskin MB, Shatz CJ (1985) Studies of the earliest generated cells of the cat's visual cortex: congeneration of the cells of the marginal zone and subplate. J Neurosci 5:1062-1075.

Manthorpe M, Engvall E, Ruoslahti E, Longo FM, Davis GE, Varon S (1983) Laminin promotes neuritic regeneration from cultured peripheral and central neurons. J Cell Biol 97:1882-1890.

Margolis RU, Margolis RK (1989) Nervous tissue proteoglycans. Dev Neurosci 11:276-288.

Marin-Padilla M (1971) Early prenatal ontogenesis of the cerebral cortex (neocortex) of the cat (Felis domestica). A Golgi study. I. The primordial neocortical organization. Z Anat Entwicklgesch 134:117145.

Marin-Padilla M (1972) Prenatal ontogenetic history of the principal neurons of the neocortex of the cat (Felis domestica). A Golgi study. II. Developmental differences and their significances. Int J Cancer 136:125-142.

Marin-Padilla M (1978) Dual origin of the mammalian neocortex and evolution of the cortical plate. Anat Embryol 152:109-126.

McConnell SK, Ghosh A, Shatz CJ (1989) Subplate neurons pioneer the first axon pathway from the cerebral cortex. Science 245:978982.

McLoon SC, McLoon LK, Palm SL, Furcht LT (1988) Transient expression of laminin in the optic nerve of the developing rat. $J$ Neurosci 8:1981-1990.

Misson JP, Edwards MA, Yamamoto M, Caviness VS Jr (1988) Identification of radial glial cells within the developing murine central nervous system: studies based upon a new immunohistochemical marker. Dev Brain Res 44:95-108.

Mjaatvedt CH, Lepera RC, Markwald RR (1987) Myocardial specificity for initiating endothelial-mesenchymal cell transition in embryonic chick heart correlates with a particulate distribution of fibronectin. Dev Biol 119:59-67.

Morest DK (1970) A study of neurogenesis in the forebrain of opossum pouch young. Z Anat Entwicklgesch 130:265-305.

Nakanishi S (1983) Extracellular matrix during laminar pattern formation of neocortex in normal and reeler mutant mice. Dev Biol 95: 305-316.

Neugebauer KM, Tomaselli KJ, Lilien J, Reichardt LF (1988) N-cadherin, NCAM, and integrins promote retinal neurite outgrowth on astrocytes in vitro. J Cell Biol 107:1177-1187.

Oohira A, Matsui F, Matsuda M, Takida Y, Kuboki Y (1988) Occurrence of three distinct molecular species of chondroitin sulfate proteoglycan in the developing rat brain. J Biol Chem 263:1024010246.

Oohira A, Matsui F, Katoh-Semba R (1991) Inhibitory effects of brain chondroitin sulfate proteoglycans on neurite outgrowth from $\mathrm{PCl}$ 2D cells. J Neurosci 11:822-827.

O'Shea KS, Rheinheimer JST, Dixit VM (1990) Deposition and role of thrombospondin in the histogenesis of the cerebellar cortex. J Cell Biol 110:1275-1283.

Perris R, Johansson S (1990) Inhibition of neural crest cell migration by aggregating chondroitin sulfate proteoglycans is mediated by their hyaluronan-binding region. Dev Biol 137:1-12.

Pixley SR, de Vellis J (1984) Transition between immature radial glia and mature astrocytes studied with a monoclonal antibody to vimentin. Dev Brain Res 15:201-209.

Raedler E, Raedler A (1978) Autoradiographic study of early neuro- genesis in rat neocortex. Anat Embryol 154:267-284.

Rakic P (1972) Mode of cell migration to the superficial layers of fetal monkey neocortex. J Comp Neurol 145:61-84.

Ramon y Cajal S (1891) Sur la structure de l'ecorce cerebrale de quelques mammiferes. Cellule 7:125-176.

Ramon y Cajal S (1911) Histologie du systeme nerveux de l'homme et des vertebres. Paris: Maloine.

Reichardt LF, Tomaselli KJ (1991) Extracellular matrix molecules and their receptors: functions in neural development. Annu Rev Neurosci 14:531-570.

Reinoso BS, O'Leary DDM (1990) Correlation of geniculocortical growth into the cortical plate with the migration of their layer 4 and 6 target cells. Soc Neurosci Abstr 16:493.

Retzius G (1893) Die Cajal'schen Zellen der Grosshirnrinde beim Menschen und bei Saugethieren. Biol Unters Neue Folge 5:1-8.

Rickmann M, Wolff JR (1985) Prenatal gliogenesis in the neopallium of the rat. Adv Anat Embryol Cell Biol 93:1-102.

Rogers SL, Letourneau PC, Palm SL, McCarthy I, Furcht LT (1983) Neurite extension by peripheral and central nervous system neurons in response to substratum-bound fibronectin and laminin. Dev Biol 98:212-220.

Rogers SL, Edson KJ, Letourneau PC, McLoon SC (1986) Distribution of laminin in the developing peripheral nervous system of the chick Dev Biol 113:429-435.

Rogers SL, Letourneau PC, Peterson BA, Furcht LT, McCarthy JB (1987) Selective interaction of peripheral and central nervous system cells with two distinct cell-binding domains of fibronectin. J Cell Biol 105:1435-1442

Sanes JR (1989) Extracellular matrix molecules that influence neural development. Annu Rev Neurosci 12:491-516.

Sauer FC (1935) Mitosis in the neural tube. J Comp Neurol 62:377405.

Schlaggar BL, O'Leary DDM (1990) Glycoconjugate boundaries outline barrels that form in visual cortex transplanted to the barrelfield of SI cortex. Soc Neurosci Abstr 16:631.

Schlaggar BL, O'Leary DDM (1991) Potential of visual cortex to develop an array of functional units unique to somatosensory cortex. Science 252:1550-1560.

Schlumpf M, Shoemaker WJ, Bloom FE (1980) Innervation of embryonic rat cerebral cortex by catecholamine-containing fibers. J Comp Neurol 192:361-376.

Schmechel DE, Rakic P (1979) A Golgi study of radial glial cells in developing monkey telencephalon: morphogenesis and transformation into astrocytes. Anat Embryol 156:1 15-152.

Schwarzbauer JE, Tamkun JW, Lemischka IR, Hynes RO (1983) Three different fibronectin mRNAs arise by alternative splicing within the coding region. Cell $35: 421-431$

Sheppard AM, Pearlman A (1990) Extracellular matrix molecules are associated with preplate cells in early neocortical development. Soc Neurosci Abstr 16:315.

Smallheiser NR, Crain SM, Reid LM (1984) Laminin as a substrate for retinal axons in vitro. Dev Brain Res 12:136-140.

Smart IHM, Smart M (1982) Growth patterns in the lateral wall of the mouse telencephalon: I. Autoradiographic studies of the histogenesis of the isocortex and adjacent areas. J Anat 134:273-298.

Snow DM, Lemmon V, Carrino DA, Caplan AI, Silver J (1990a) Sulfated proteoglycans in astroglial barriers inhibit neurite outgrowth in vitro. Exp Neurol 109:111-130.

Snow DM, Steindler DA, Silver J (1990b) Molecular and cellular characterization of the glial roof plate of the spinal cord and optic tectum: a possible role for a proteoglycan in the development of an axon barrier. Dev Biol 138:359-376.

Stallcup WB, Pytela R, Ruoslahti E (1989) A neuroectoderm-associated ganglioside participates in fibronectin receptor-mediated adhesion of germinal cells to fibronectin. Dev Biol 132:212-229.

Steindler DA, Cooper NGF, Faissner A, Schachner M (1989) Boundaries defined by adhesion molecules during development of the coerbral cortex: the J1/tenascin glycoprotein in the mouse somatosensory cortical barrel field. Dev Biol 131:243-260.

Steindler DA, Faissner A, Schachner M (1990) Brain "cordones": transent boundaries of glia and adhesion molecules that define developing functional units. Commun Dev Neurobiol 1:29-60.

Sternberg J, Kimber SJ (1986) Distribution of fibronectin, laminin and entactin in the environment of migrating neural crest cells in early mouse embryos. J Embryol Exp Morphol 91:267-282.

Stewart GR, Pearlman AL (1987) Fibronectin-like immunoreactivity 
in the developing cerebral cortex. J Neurosci 7:3325-3333.

Takahashi T, Misson J-P, Caviness VS Jr (1990) Glial process elongation and branching in the developing murine neocortex: a qualitative and quantitative immunohistochemical analysis. J Comp Neurol 302:15-28.

Tan SS, Crossin KL, Hoffman S, Edelman GM (1987) Asymmetric expression in somites of cylotactin and its proteoglycan ligand is correlated with neural crest cell distribution. Proc Natl Acad Sci USA 84:7977-7981.

Tomaselli KJ, Reichardt LF (1988) Peripheral motoneuron interactions with laminin and Schwann cell-derived neurite-promoting molecules: developmental regulation of laminin receptor function. J Neurosci Res 21:275-285.

Tomaselli KJ, Damsky CH, Reichardt LF (1988) Purification and characterization of mammalian integrins expressed by a rat neurnnal cell line (PC12): evidence that they function as alpha/beta heterodimeric receptors for laminin and type IV collagen. J Cell Biol 107: $1241-1252$.

Tosney KW, Landmesser L (1985) Development to the major pathways for neurite outgrowth in the chick hindlimb. Dev Biol 109:193214.

Tucker RP, Erickson CA (1984) Morphology and behavior of quail neural crest cells in artificial three-dimensional extracellular matrices. Dev Biol 104:390-405.

Valverde F, Facal-Valverde MV (1987) Transitory population of cells in the temporal cortex of kittens. Dev Brain Res 32:283-288.
Valverde F, Facal-Valverde V, Santacana M, Heredia M (1989) Development and differentiation of early generated cells of sublayer VIb in the somatosensory cortex of the rat: a correlated Golgi and autoradiographic study. J Comp Neurol 290:118-140.

Verney C, Berger B, Adrien J, Vigny A, Gay M (1982) Development of the dopaminergic innervation of the rat cerebral cortex. A ligh microscopic immunocytochemical study using anti-tyrosine hydroxylase antibodies. Dev Brain Res 5:41-52.

Villiger B, Kelley DG, Engleman W, Kuhn C, McDonald JA (1981) Human alveolar macrophage fibronectin: synthesis, secretion, and ultrastructural localization during gelatin-coated latex particle binding. J Cell Biol 90:711-720.

Voigt T (1989) Development of glial cells in the cerebral wall of ferrets: direct tracing of their transformation from radial glia into astrocytes. J Comp Neurol 289:74-88.

Woo TU, Beale JM, Finlay BL (1990) Dual fate of subplate neurons in the rodent. Soc Neurosci Abstr 16:836.

Wood JN, Lathangue NB, McLachlan DR, Smith BJ, Anderton BH, Dowding AJ (1985) Chromatin proteins share antigenic determinants with neurofilaments. J Neurochem 44:149-154.

Woolsey TA, Van der Loos H (1970) The structural organization of layer IV in the somatosensory region (SI) of mouse cerebral cortex: the description of a cortical field composed of discrete cytoarchitectonic units. Brain Res 17:205-242. 